\title{
Iconografía musical en el románico de la provincia de Soria ${ }^{1}$
}

\section{Musical iconography in the Romanesque of the province of Soria}

\author{
Nerea RODRÍGUEZ PÉREZ \\ Funcionaria de carrera en la especialidad de Música, IES Santa Teresa de Jesús (Madrid) \\ nerea.rodriguezperez@educa.madrid.org
}

Recibido: 05/10/2013

Aprobado: 03/12/2013

Resumen: El trabajo parte del análisis iconográfico de la portada de Santo Domingo de Soria y el posterior recorrido por todo el románico de esa provincia con la elaboración de rutas en busca del resto de fuentes musicales. El resultado de este trabajo de investigación es la recopilación de toda la iconografía musical románica de la provincia de Soria, sus posibles vías de influencia y la catalogación de las fuentes, con una relación de escenas musicales localizadas en el románico de esa provincia, y una serie de fuentes musicales encontradas en el exterior de 20 localidades de las 210 examinadas.

Palabras clave: Románico rural, Soria, iconografía musical, instrumentos musicales medievales.

Abstract: This study begins with the iconographic analysis of the portal of Santo Domingo in Soria and spreads to the itinerary of Romanesque remains throughout this province, with the elaboration of routes in search of the remaining musical sources. The result of this study is the compilation of all the Romanesque musical iconography in the province od Soria, its possible means of influence and the catalogation of the sources, with a catalogue of musical scenes located in the Romanesque remains in this province and a series of outdoor musical sources found in 20 of the 210 examined locations.

Key words: Rural Romanesque, Soria, musical iconography, medieval musical instruments.

Sumario: 1. ¿Cómo suena el románico? 2. Caminos sorianos. 2.1. Soria rural. 2.2. Vías de influencia. 3. Iconografía musical. 3.1. Programas iconográficos. 3.2. Catálogo de elementos musicales. 3.2.1. Cordófonos. 3.2.2. Aerófonos. 3.2.3. Membranófonos. 3.2.4. ¿Cantores? 4. Conclusiones. Fuentes y Bibliografía.

$$
* * * * *
$$

\section{1. ¿Cómo suena el románico?}

Siempre se ha explicado el sonido del románico comparando las sólidas iglesias románicas con la austeridad del canto gregoriano. La ausencia de polifonía sirve para explicar esos muros contundentes y esas líneas rectas que sobreviven al tiempo y a la civilización. Es posible que el interior de las grandes iglesias románicas sonaran a gregoriano, pero ¿y el exterior?, ¿qué tienen en común una máscara, un animal de dos cabezas, una escena itifálica, un músico tocando un arpa con cara de satisfacción y una adoración recatada?

Después de ver cientos de imágenes en los exteriores de las iglesias románicas, llegamos a la conclusión de que había mucha polifonía fuera de las iglesias, infinidad de

\footnotetext{
${ }^{1}$ Este escrito tiene como origen la tesina "Iconografía Musical en el Románico de la Provincia de Soria", desarrollada en junio de 2004 bajo la dirección de la Dra. Carmen Julia Gutiérrez y la Dra. Cristina Bordas Ibáñez para el programa de doctorado "La Música en España e Hispanoamérica: Métodos y Técnicas Actuales de Investigación", de la licenciatura "Historia y Ciencias de la Música" de la Universidad Complutense de Madrid.
} 
voces y miradas que encontraban en esas imágenes el reflejo de un mundo entre la realidad y la ficción, entre la risa y el miedo, entre los habitantes de los territorios repoblados en el siglo XII y las prisas en construir iglesias, a veces levantadas y decoradas por manos inexpertas, en ocasiones el único camino hacia la ausencia de prejuicios. Quizás esta liberación del modelo, por incapacidad, por prisa o por un alarde de improvisación, hizo tan peculiar la decoración de estas pequeñas iglesias y ermitas.

Hoy en día percibimos esa polifonía en sentido estético al levantar la vista y rebuscar en los canecillos, los capiteles y las arquivoltas de este románico, sencillo en apariencia, pero que describe perfectamente una sociedad que usó la imagen para retratarse, para temer, para aprender y para reír. Es decir, utilizó la imagen de una manera muy similar a como lo hacemos en pleno siglo XXI.

Nosotros emplearemos esas imágenes para rellenar poco a poco los vacíos existentes en el conocimiento de la música medieval, conscientes de que muchas de estas imágenes no corresponden a escenas musicales reales y que la copia de copia, tan frecuente en este tipo de románico, transforma la realidad de los modelos primigenios.

Estos modelos, supuestamente dibujados para uso de los maestros canteros, pueden a su vez tener un prototipo muy cercano al instrumento real (póngase por caso del pórtico de la Gloria de Santiago de Compostela ${ }^{2}$ ), copiarse de los instrumentos representados en los Beatos de Liébana ${ }^{3}$ o dibujarse de memoria, a partir de una idea del instrumento más o menos general y sin entrar en detalle.

Los instrumentos que vamos a ver no tienen la precisión de los de Santiago, aparte de ser de una escuela totalmente diferente, ni tienen nada que ver con los instrumentos que aparecen en una copia de los Comentarios al Apocalipsis del Beato de Liébana, ${ }^{4}$ que estuvo en El Burgo de Osma ${ }^{5}$ por aquellos años y que aún sigue estando guardada en su catedral. Por lo que el uso de modelos desvirtuados o modelos dibujados a grandes trazos, sin entrar en el detalle, es la hipótesis más verosímil después de analizar los instrumentos que se presentarán a continuación.

\section{Caminos sorianos}

Los caminos actuales que comunican y marcan las fronteras de Soria con sus numerosos vecinos no se corresponden con los mapas que las diferentes diócesis defendían en la época que nos ocupa con el fin de tener todo el terreno posible a su cargo.

\footnotetext{
${ }^{2}$ BORDÁS IBÁÑEZ, Cristina: “Música y artes plásticas. Una presentación y otra mirada más al Pórtico de la Gloria." Campos Interdisciplinares de la Musicología. Volumen II. Actas del V Congreso de la Sociedad Española de Musicología (Barcelona, 25-28 de octubre de 2000), Madrid, 2001, p. 12271242; Villanueva ABelairas, Carlos: El pórtico de la Gloria. Música, arte y pensamiento ed. Xunta de Galicia, A Coruña, 1988; LóPEZ-CALO, José (coordinador): Los instrumentos del Pórtico de la Gloria. Su reconstrucción y la música de su tiempo. Vol. 1 y 2 ed. Fundación Pedro Barrié de la Maza Conde de Fenosa, La Coruña, 1993; LóPEZ-CALO, José: La música Medieval en Galicia. La Coruña: Fundación Pedro Barrié de la Maza, 1982.

3 Álvarez MARTíneZ, Rosario: "La iconografía medieval de los Beatos de los siglos X y XI y su procedencia", Anuario del Departamento de Historia y Teoría del Arte, Univ. Autónoma de Madrid, 1993. p. 201-218; Romero De Lecea, Carlos: Trompetas y cítaras en los códices de Beato de Liébana. Madrid: RABASF, 1977.

${ }^{4}$ BeAto De LiÉBAnA: Apocalipsis de San Juan Apóstol. Ed. Vicent García Editores, S.A. Valencia, 1992.

${ }^{5}$ La catedral de Burgo de Osma. Guía turística, edita el Cabildo de la S. I. Catedral, Soria, 1975. p. 2530; LOPERRAeZ CORVAlan, Juan: Descripción histórica del Obispado de Osma, 3 volúmenes, ed. Turner, Madrid, 1788; VAL VALDIVIESO, Ma Isabel del: "Introducción al estudio del obispado de Osma en la Baja Edad Media”, Celtiberia, no 70,1985. Centro de Estudios Sorianos. p. 211-252.
} 
La infinidad de rectificaciones de las fronteras que se hicieron desde el siglo X al XIII ${ }^{6}$ ha sido la razón principal de que no hagamos el estudio del románico soriano siguiendo las fronteras diocesanas de Osma ${ }^{7}$, Sigüenza, Tarazona, Calahorra y Burgos, sino las actuales, tal y como vemos en la Fig. 1.

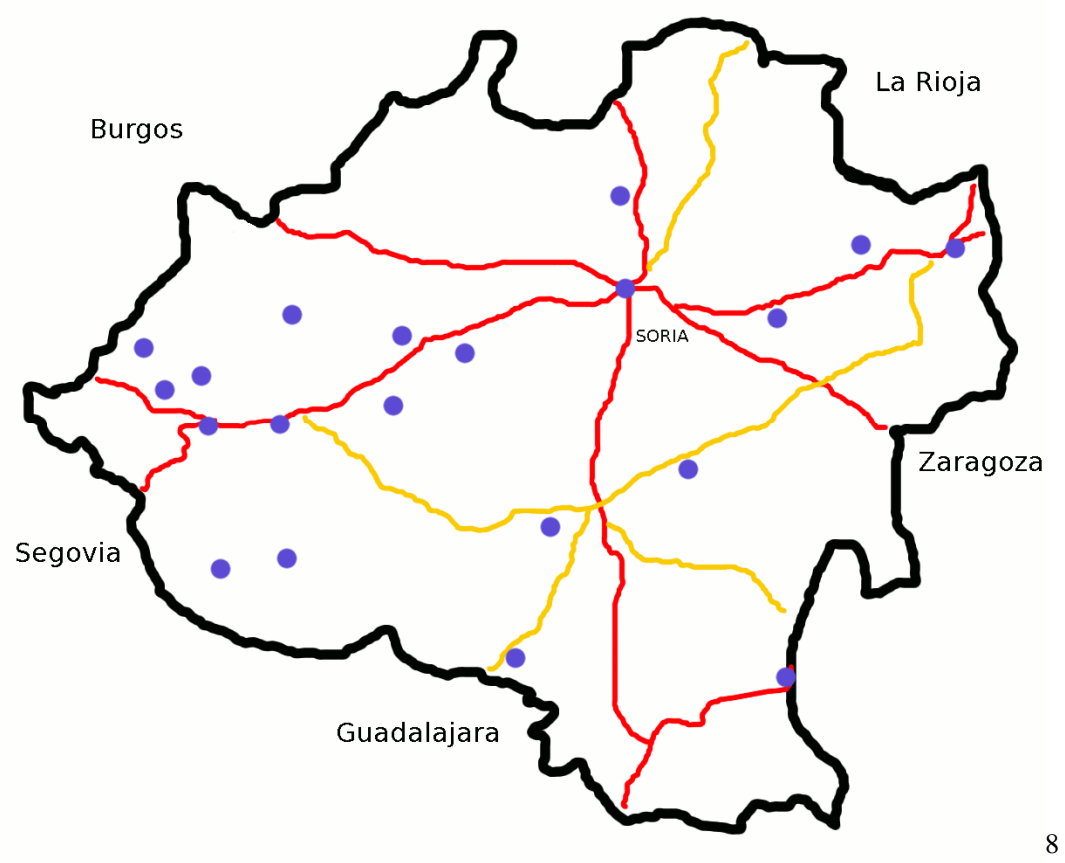

Fig. 1: Mapa de elaboración propia basado en Mapa provincial de Soria. Ed. Ministerio de Fomento, Instituto Geográfico Nacional, Madrid, 1999. (RODRÍGUEZ PÉREZ, Nerea. 2013)

\subsection{Soria rural}

Estos caminos enlazan un total de 210 pueblos con patrimonio románico. Algunos de esos pueblos están abandonados o habitados solo por uno o dos vecinos que esperan pacientemente a que el verano haga regresar a los que se fueron a las ciudades y que mantienen en dichos pueblos una casita de veraneo.

De entre estos 210 pueblos, 20 tienen representaciones musicales en los canecillos, capiteles, pórticos o arquivoltas de sus iglesias. Y en esos 20 pueblos (o ciudades, ya que incluimos Soria capital) hay un total de 55 instrumentos musicales y cuatro cantantes.

${ }^{6}$ CASA Martínez, Carlos de la: "Datos para la historia del monasterio de Santa Clara de Soria. Catálogo sifilográfico de su archivo", Celtiberia, nº7, Centro de estudios sorianos, 1986. p. 58-68; VV.AA.: Enciclopedia del Románico en Castilla y León. Burgos. Ed. Fundación de Santa María La Real. Centro de Estudios del Románico. Dirección: M.A. García Guinea y J.M. Pérez González, Aguilar del Campoo, 2002. Vol. 1, 2, 3 y 4; FríAs BALSA, José Vicente: "Los obispos de Osma y el Dogma de la Inmaculada", Revista de Soria, $\mathrm{n}^{\circ}$ 36, 1978; GoNZÁLEZ, Julio: El reino de Castilla en la época de Alfonso VIII. ed. CSIC, Madrid, 1960; IZQUIERDO BERTIZ, José María: "El arte Románico en Soria", Historia de Soria, ed. Centro de estudios Sorianos, Soria, 1985. p. 265-296; LOPERRAEZ 1788; MORENO Ayola, Eugenio y TARACENA AguiRre, Blas: Inventario de los Archivos Históricos Municipales y Especiales de la Provincia de Soria. Soria, 1983. p. 97, 98, 104; NúÑEZ MARQUES, Vicente.: Guía de la Iglesia Catedral del Burgo de Osma y Breve Historia del Obispado de Osma. Burgo de Osma, 1949.

${ }^{7}$ VV.AA. Soria Románica. El arte Románico en la Diócesis de Osma-Soria. Por la Fundación de Santa María La Real. Aguilar de Campoo (Palencia), 2001.

${ }^{8}$ Se trata de un mapa donde vemos los límites de la provincia y en el que se señalan las travesías que comunican sus pueblos. Están marcados con círculos las ubicaciones de escenas musicales encontradas. En sucesivos apartados aparecerá este mismo mapa pero citando las localidades por tipología de instrumentos. Se mantendrá la localización de las demás localidades para hacernos una imagen general de cada tipología en el conjunto total. 
Son pueblos humildes en su mayoría, sin casi acceso muchos de ellos y abandonados otros tantos. Y es que la Soria rural ha convivido de manera totalmente natural con su románico, y no se percibe como una reliquia artística, sino como algo que siempre ha estado ahí, totalmente integrado en los paisajes y en el desarrollo urbanístico y humano de las localidades. Como curiosidad podemos encontrarnos con numerosos "grafitis" de los años 20 o 30 del siglo pasado, tallados en las piedras y portadas de ermitas, o ver claramente la forma desgastada de las columnas por el paso del tiempo y también por el roce de los aldeanos que se sentaban en sus bases para reunirse a la sombra de esos edificios frescos y consistentes, ahora ya prácticamente vacíos y casi siempre cerrados.

Para recorrer todo el románico soriano primero hubo que localizarlo analizando varias fuentes, ${ }^{9}$ y se crearon rutas para hacer recorridos de entre 15 y 20 pueblos aproximadamente. Se confeccionaron así 13 rutas que llevaban a los lugares más inhóspitos de la provincia y a las miradas curiosas de los a veces temerosos aldeanos, nada acostumbrados a este tipo de visitas.

Los pueblos y sus iglesias, Catedrales o ermitas que esconden las 59 pequeñas joyas musicales que veremos a lo largo del texto son:

1. Ágreda: iglesia de San Juan Bautista.

2. Alpanseque: iglesia de Nuestra Señora de la Asunción.

3. Añavieja: iglesia de Santa Eugenia.

4. Barca: iglesia de Santa Cristina.

5. Berzosa: iglesia de San Martín de Tours.

6. Bocigas de Perales: iglesia de San Pedro.

7. Calatañazor: ermita de la Virgen de la Soledad.

8. Caracena: iglesia de San Pedro Apóstol.

9. El Burgo de Osma: Catedral de Santa María.

10. Nafría la Llana: iglesia de Nuestra Señora de la Natividad.

11. Nepas: iglesia de San Adrián.

12. Montejo de Tiermes: ermita de Santa María de Tiermes.

13. Rejas de San Esteban: iglesia de San Ginés.

14. San Esteban de Gormaz: iglesia de San Miguel, iglesia de Nuestra Señora del Rivero.

15. Santa María de Huerta: monasterio de Santa María de Huerta.

16. Soria: Santo Domingo, claustro de la Concatedral de San Pedro.

17. Tera: iglesia de Nuestra Señora del Carmen.

18. Torreandaluz: iglesia de Santo Domingo de Silos.

19. Tozalmoro: iglesia de San Juan Bautista.

20. Ucero: ermita de San Bartolomé.

\footnotetext{
${ }^{9}$ VV.AA.: Enciclopedia del Románico en Castilla y León. Soria, vol.1, 2, 3. Ed. Fundación de Santa María La Real. Centro de estudios del románico: M.A. García Guinea y J.M. Pérez González. 2002, Aguilar del Campoo; Herbosa, Vicente: El Románico en Soria. Ed. Lancia, León, 1999; GARCÍA I Acón, F., Nin i Catalá, J. : Soria. Plano de ciudad. Mapa de provincia. Rutas turísticas. Índices toponímicos. ed. Distrimapas telstar, Barcelona, 2000; GAYA NUÑO, Juan Antonio: El románico en la provincia de Soria. ed. Biblioteca de Historia del Arte del consejo superior de investigaciones científicas, centro de estudios sorianos, Madrid, Edición facsímil, 2003; IZQUIERDO BERTIZ 1985: 265296. LAFORA, Carlos: Por los caminos del Románico Porticado. Una fórmula arquitectónica para albergar el derecho a la libertad. Ed. Encuentro. Colección La noche de los tiempos. Abril, Madrid, 1988; VV.AA.: Soria Románica. El arte Románico en la Diócesis de Osma-Soria. Por la Fundación de Santa María La Real. Aguilar de Campoo (Palencia), 2001.
} 


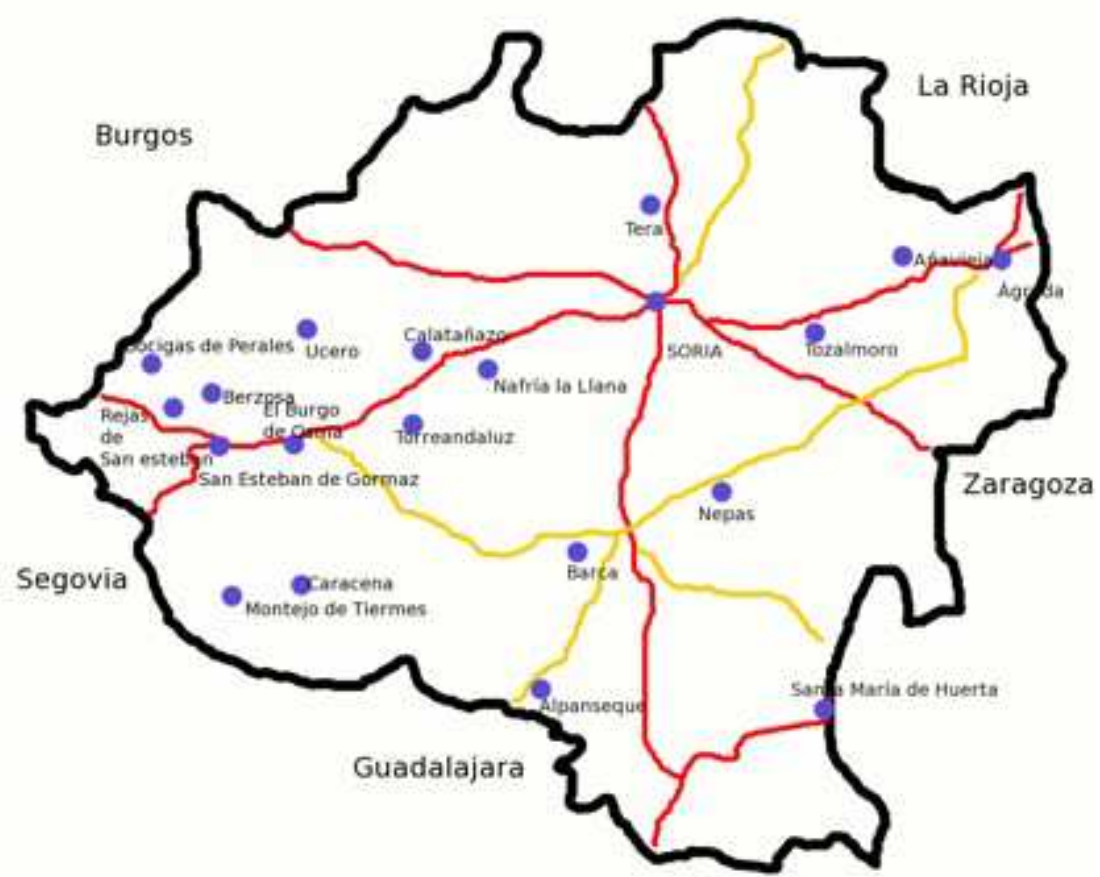

Fig. 2: Representación de todas las localidades sorianas con iconografía musical en su arquitectura románica. (RODRÍGUEZ PÉREZ, Nerea. 2013)

\subsection{Vías de influencia}

La curiosa amalgama de imágenes que vamos a presentar es el resultado de la mezcolanza que se dio en las zonas fronterizas durante la Edad Media. La tesis que avalo con este trabajo en cuanto a las raíces románicas ${ }^{10}$ escultóricas de esta zona de Castilla es la del encuentro entre la influencia de los escultores de origen aragonés ${ }^{11}$, de maestros procedentes del monasterio de Silos ${ }^{12}$ y de la Catedral de El Burgo de Osma. También defiendo la hipótesis de que el pórtico de la Gloria de Santiago ${ }^{13}$ de Compostela y el pórtico de la iglesia de Santo Domingo ${ }^{14}$ de Soria (la fuente más importante de este

\footnotetext{
${ }^{10}$ FOCILlON, Henry: La escultura románica. Investigaciones sobre la historia de las formas. Ed. Akal.
} Arte y Estética. Madrid, 1986.

PITA ANDRADE, José Manuel: Artes y artistas. Escultura románica en Castilla. Los maestros de Oviedo y Ávila. Ed. Instituto Diego Velázquez del CSIC Madrid, 1933.

11 GAYA NuÑo 2003; “Artistas y Artesanos del Románico Español”, Goya, 130, 1976. p. 214-219; BALLESTER, Jordi: Els instruments musical en els retaules marians tardomedievals a la Corona Catalano-Aragonesa. Tesis de licenciatura, Univ. Autónoma de Barcelona, 1988; ANGLÉs, Higinio: Historia de la música medieval en Navarra. Diputación Floral de Navarra, Institución "Príncipe de Viana", Pamplona, 1970; Cobreros, Jaime: Itinerarios románicos por el Alto Aragón. El símbolo como expresión de lo sagrado. Ed. Encuentro, Madrid, 1989.

${ }^{12}$ Frontón SIMÓN, Isabel: "El pórtico de la iglesia románica del monasterio de Silos. Datos para la reconstrucción iconográfica de su portada exterior", Boletín del Museo e Instituto Camón Aznar, $\mathrm{n}^{\circ}$ LXIV, 1996.

13 VV.AA. Enciclopedia Universal Ilustrada Europeo Americana. Ed. Espasa-Calpe S.A. Tomo 54 "Santiago" p. 249, 252, 264-266.

${ }^{14}$ Artigas y COROMINAS, Pelayo: "El monasterio de Santa Clara de Soria". Celtiberia, nº71, 1986; Castilla y León. Soria plano-guía. Ed. Junta de Castilla y León, 2002; DAVY, Marie Madelaire: Iniciación a la simbología románica: el siglo XII. Ed. Akal, Torrejón de Ardoz, 1996; GóMEZ BARRERA, Juan Antonio: "Aproximación al estudio iconográfico de la primera arquivolta del Pórtico de Santo Tomé (Soria)”. Butlletí de la Reial Académia Catalana de Belles Arts de Sant Jordi, XIV, 2000; 
estudio de iconografía) no fueron realizados por el mismo taller, aun cuando hay semejanza en el tratamiento de la temática de los veinticuatro ancianos. ${ }^{15}$

Podemos encontrar documentación sobre la influencia francesa ${ }^{16}$ a nivel arquitectónico (no escultórico), e incluso la de los miniaturistas ingleses ${ }^{17}$ que acompañaban la corte de Alfonso VIII ${ }^{18}$. Pero nos centraremos en la hipótesis de la influencia silense, aportando datos al menos para la iglesia de Santo Domingo de Soria. Aparte de los argumentos esgrimidos por Isabel Frontón, hemos comparado la representación de los Veinticuatro Ancianos del Apocalipsis ${ }^{19}$ localizada en otras tres iglesias de clara influencia silense, a saber: ${ }^{20}$

Ahedo de Butrón: iglesia de Nuestra Señora de la Asunción.

Moradillo de Sedano: iglesia de San Esteban Protomártir.

Cerezo del Río Tirón: restos dispersos de Nuestra Señora de la Llana.

Hay otras muchas iglesias dentro de este marco de influencia que han sido relacionadas con Santo Domingo de Soria, como Gredilla de Sedano, Soto de Bureba y Butrera, pero, como en ellos no hay representaciones musicales, hemos preferido centrar la comparación en las iglesias con las que tienen el programa iconográfico de los Veinticuatro Ancianos.

De manera general podemos decir que los maestros encargados de las obras y de las esculturas no son los mismos en ninguna de las tres iglesias, y tampoco ninguno de ellos fue el artífice de la portada de Santo Domingo de Soria.

Se ven diferencias claras tanto en el tratamiento del tema como en la pericia de los escultores, hasta tal punto que en Moradillo de Sedano no se representan veinticuatro

JimÉnez GonZAlo, Carmelo: Santo Domingo. Iglesia y Monasterio. "Historia” Ed. El autor, Soria, 1985; Marichalar, Amalio de (Conde de Ripalda): Iglesia Románica de Santo Domingo (antigua parroquia de Santo Tomé). Soria, 1972; PERALES DE LA CAL, Ramón: "Iconografía musical arqueológica de Soria" Actas del primer Symposium de Arqueología Soriana. Soria, 1984. p. 541-555; VV.AA. Santo Domingo de Soria la presencia del color. ed. Biop, S.L. 1994; VII Centenario de las Clarisas en Soria. Ed. Centro de Estudios Sorianos. Consejo Superior de Investigaciones Científicas, Soria, 1986. p. 202-207.

15 VV.AA.: Ciclo de conferencias sobre el Románico y el Camino de Santiago. Organizado por el Departamento de Cultura de la Escma. Diputación Provincial de Palencia, Palencia, 1983; El pórtico de la Gloria. Música, arte y pensamiento. ed. Xunta de Galicia, A Coruña, 1988; López-Calo 1993.

${ }^{16}$ GAYA NuÑO, Juan Antonio: "Poitiers y Soria, hermanas románicas”. Diario de Barcelona. (14-XII1963); Karge, Henrik: La catedral de Burgos y la arquitectura del siglo XIII en Francia y España. Ed. Consejería de Cultura y Turismo, Valladolid, 1995; www.soriaymás.es : Influencias francesas en el Románico Soriano, Hermetismo y alquimia en Santo Tomé de Soria.

17 OCÓN ALONSO, David: “Alfonso VIII, la llegada de las corrientes artísticas de la corte inglesa y el bizantinismo de la escultura hispana a finales del siglo XII". en Curso de cultura medieval: Aguilar de Campoo: “Alfonso VIII y su época”. Palencia, 1992. p. 307-320.

${ }^{18}$ Diago Hernando, Máximo: Estructuras de poder en Soria a fines de la Edad Media. ed. Consejería de Cultura y Turismo. Junta de Castilla y León, 1993. p. 17-23, 367, 368; II Curso de Cultura Medieval. "Seminario Alfonso VIII y su época". Aguilar del Campoo 1-6 Octubre 1990. ed. Centro de estudios del Románico; Revista de Investigación. "Repoblación de integración política en el reino de Castilla del ámbito de la tierra de Soria”. Soria, 1991-1992. Ed. Colegio Universitario de Soria. Estudio extraído de RICUS (Geografía e historia) XI, 3 (1991-1992) p. 37-58; PALACIOS MADRID, Francisco: "Los señores de Soria y su castillo en el siglo XII". Celtiberia, nº53, 1977; PÉREZ-RIOJA, José Antonio: Historia de Soria. Ed. Centro de Estudios Sorianos (CSIC). Soria, 1985. p. 217-242; ZAMORA LuCAS, F: "La dehesa de San Andrés en la historia" Celtiberia, nº45, 1973. p. 25-35.

19 GonZÁLEZ HerranZ, Raimundo: "Representaciones musicales en la iconografía medieval". Anales de Historia del Arte, $\mathrm{n}^{\circ}$ 8, 1998. p. 67-96.

${ }^{20}$ VV.AA. 2002: Vol. 1, 2, 3 y 4; KING, Georgiana Goddard: "The problem of the Duero" Art Studies, 3, 1926. p.3-11. 
ancianos, sino veinte, y se incorporan aerófonos, proponiendo otros instrumentos que no concuerdan con los genéricos cordófonos (llamados "cítaras" en el texto apocalíptico).

Los tímpanos de las cuatro iglesias, contando la de Santo Domingo, son muy parecidos. Esto es muy importante, teniendo en cuenta que en toda Soria se conservan solo ocho ${ }^{21}$ y en Burgos, doce, siendo las dos provincias castellanas más prolíferas en cuanto a tímpanos.

Con respecto a los instrumentos, la fisonomía, la vestimenta y la posición de los ancianos, debemos decir que entre las cuatro fuentes hay más similitudes que diferencias, lo que aporta suficientes datos para afirmar que todas estas fuentes tienen una base común: Silos.

De todos los maestros canteros que participaron en las tallas escultóricas, a nuestro juicio el más diestro es el de Santo Domingo de Soria. Sus personajes son menos hieráticos, tienen una expresión más viva, signo claro de evolución. Sin embargo, no entra tanto en detalle en los instrumentos como lo hace, por ejemplo, el escultor de Ahedo de Butrón. Santo Domingo desarrolla una escultura monumental, con un programa iconográfico $^{22}$ mucho más rico y elaborado que en las demás fuentes, por lo que podemos pensar que el autor fue de los mejores discípulos del taller de Silos.

Según la teoría del sistema de aprendizaje de los maestros canteros y su aplicación en el mundo rural, expuesta por Inés Ruiz Montejo ${ }^{23}$, Santo Domingo de Soria podría haber sido una de las iglesias llamadas "cabeza de taller", donde artesanos locales aprendieron el oficio trabajando en su construcción, y que estos a su vez enseñaron a otros, y así sucesivamente. A lo largo de los años se fueron dispersando por la provincia y dejando su obra, de manera que un porcentaje altísimo de las iglesias o ermitas, por pobres que parezcan, tienen algún tipo de adorno escultórico.

Está claro que la Catedral de Santa María en El Burgo de Osma tuvo mucho que decir en el románico rural de la zona; por poner un ejemplo, según Félix Palomero, ${ }^{24}$ en la ermita de Santa María de Tiermes (Montejo de Tiermes), se localizan dos maestros canteros, el más diestro de ellos procedente de la segunda escuela del monasterio de Silos, y su obra es muy semejante a los restos románicos del claustro de la Catedral de El Burgo de Osma.

Cabe pensar que la mayor influencia en la provincia es silense, dejando para las localidades cercanas a Aragón, como, por ejemplo, Ágreda ${ }^{25}$, la parte de influencia de los maestros aragoneses ${ }^{26}$, sin olvidar la de los artistas mozárabes ${ }^{27}$, claramente relacionados con la fisonomía de muchos de los personajes que portan los instrumentos que se presentan en este trabajo.

\footnotetext{
${ }^{21}$ Ridruejo GIL, María Antonia y María del Pilar : "Cuatro frontales románicos de Soria" Archivo Español de Arte, 1945. p. 3-12; RUIZ EZQUERDO, Juan José: "Los tímpanos románicos sorianos" Celtiberia XXXV, 1985 p.35-62.

${ }^{22}$ SAINZ, Elena: "Estudio Iconográfico y simbólico de la fachada de Santo Domingo", Celtiberia n ${ }^{\circ}$ 66, Soria. p. 363-372.

${ }^{23}$ RuIZ MONTEJO, Inés: “Concepto y método del románico rural” Anales de Historia del Arte 1, 1989 p. 21-37.

${ }^{24}$ PALOMERo ArAgón, Félix: "Aproximación a la escultura monumental Románica de la Ermita de Santa María de Tiermes.” Celtiberia nº 73. ed. Centro de Estudios Sorianos, Soria,1987. p. 127-154.

${ }^{25}$ GAYA NUÑO 2003. : p. 260.

${ }^{26}$ BALLESTER 1988.; ANGLÉS 1970.

${ }^{27}$ REGUERAS, Fernando: La arquitectura mozárabe en León y Castilla. Ed por Junta de Castilla y León, 1990.
} 


\section{Iconografía musical ${ }^{28}$}

Dividiremos este apartado en dos secciones, la primera dedicada a los programas iconográficos más relevantes y la segunda a la exposición de los elementos de todo el románico de la provincia por tipología de escenas musicales.

\subsection{Programas iconográficos}

De las 22 construcciones en las 20 localidades con iconografía musical, cuatro son las iglesias con programas iconográficos de más de un elemento musical que puedan estar relacionados entre sí. Descartamos en este punto elementos como los canecillos, que, aunque pueden tener relación entre ellos, no hemos percibido que tuvieran especial dependencia desde un punto de vista musical.

Los programas serán expuestos muy brevemente con excepción del motivo de los Veinticuatro Ancianos del Apocalipsis, de la iglesia de Santo Domingo de Soria, claramente la fuente iconográfica más rica de todo el románico soriano. Los programas se encuentran en las siguientes localidades:

\section{Torreandaluz}

Iglesia de Santo Domingo. Capitel de la portada.

Se trata de la representación de cuatro músicos en el primer capitel (comenzando por la izquierda) de la portada de esta iglesia construida a finales del siglo XII. Los cuatro capiteles de la portada representan los siguientes programas: ${ }^{29}$

1) Los cuatro músicos ya citados.

2) Sansón desquijarando a un león.

3) Motivos vegetales.

4) Lucha ecuestre.

Los cuatro músicos podrían estar relacionados con el segundo capitel, si consideramos a éstos como el Rey David y un grupo de intérpretes, aunque también podrían ser escenas independientes. ${ }^{30}$

Los músicos portan los siguientes instrumentos:

\footnotetext{
${ }^{28}$ ÁLVAREZ MARTíNEZ, Rosario: "Los instrumentos musicales en los códices alfonsinos: su tipología, su uso y su origen. Algunos problemas iconográficos", Revista de Musicología, x, 1, 1987. p. 67-104; Los instrumentos medievales en la plástica española durante la Edad Media, Tesis doctoral. Univ. Complutense de Madrid, 1982; BORDAS, Cristina; REY, José; DE VICENTE, Antonio; "Bibliografía sobre iconografía musical española", AEDOM Boletín de la Asociación Española de Documentación Musical. Año 1, nº1. Enero-Junio, 1994. p. 13-57; Addenda I en idem, II, 1, 1995. p. 81-88. Addenda II en idem, V, 2, 1998. p. 85-92; JUAN I NEBOT, M. Antònia: "Versión castellana de la clasificación de instrumentos musicales según Erich von Hornbostel y Curtt Sachs (Galpin Society Journal XIV, 1961)”, Nasarre, XIV, 1 , 1998. pp. 365-387; REY, Juan José y NAVARRO, Antonio: Los instrumentos de púa en España. Bandurria, cítola y "laudes españoles" ed. Alianza. Madrid, 1993; Ríos Álvaro, Koldo: "Lista de Instrumentos de Música Occidentales. Anotada desde un punto de vista iconográfico" Terence Ford, Traducida y Adaptada al español por Koldo Ríos Álvaro. Colección Cuadernos de Documentación Musical $\mathrm{n}^{\mathrm{o}}$ 2. Asociación Española de Documentación Musical, 1999; VV.AA.: "IMAGENesMUSICA", Proyecto Iconografía Musical UCM, edita AEDOM, 2012.

${ }^{29}$ VV.AA. 2002: 1099-1102.

${ }^{30}$ VV.AA. 2002: 1101.
} 


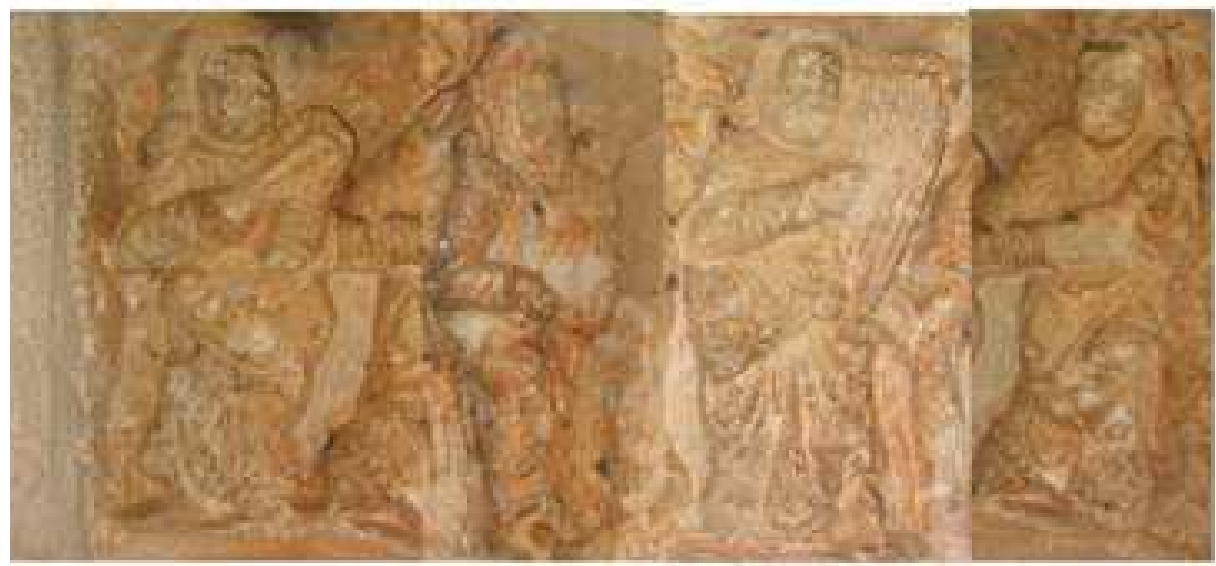

1

2

3

4

Fig. 3: Programa iconográfico en la iglesia de Santo Domingo (Torreandaluz).

(RODRÍGUEZ PÉREZ, Nerea. 2013)

1) Viola con arco sobre hombro.

2) Viola con arco sobre pierna.

3) Rota.

4) Tipo laúd.

\section{San Esteban de Gormaz}

Iglesias de San Miguel y de Nuestra Señora del Rivero. Capiteles de las galerías porticadas.

Estas dos iglesias son conocidas por tratarse de los testimonios más antiguos del románico soriano. ${ }^{31}$ Las esculturas de ambas iglesias están íntimamente relacionadas, aunque notamos mayor esmero en la iglesia de Nuestra Señora del Rivero. La iglesia de San Miguel además de ser construida unos años antes, es considerada un modelo de gran difusión, por ser cabeza de serie de la característica "galería porticada", tan típica en todo el románico soriano.

El programa iconográfico que presentamos es el de tañedores de viola con arco acompañados por personajes, quizás femeninos, en posible posición de cantar. La escena se repite en ambas iglesias, además de ir acompañados por dos instrumentistas más en los capiteles, y uno en un canecillo, difícil de identificar por la gran altura del edificio.

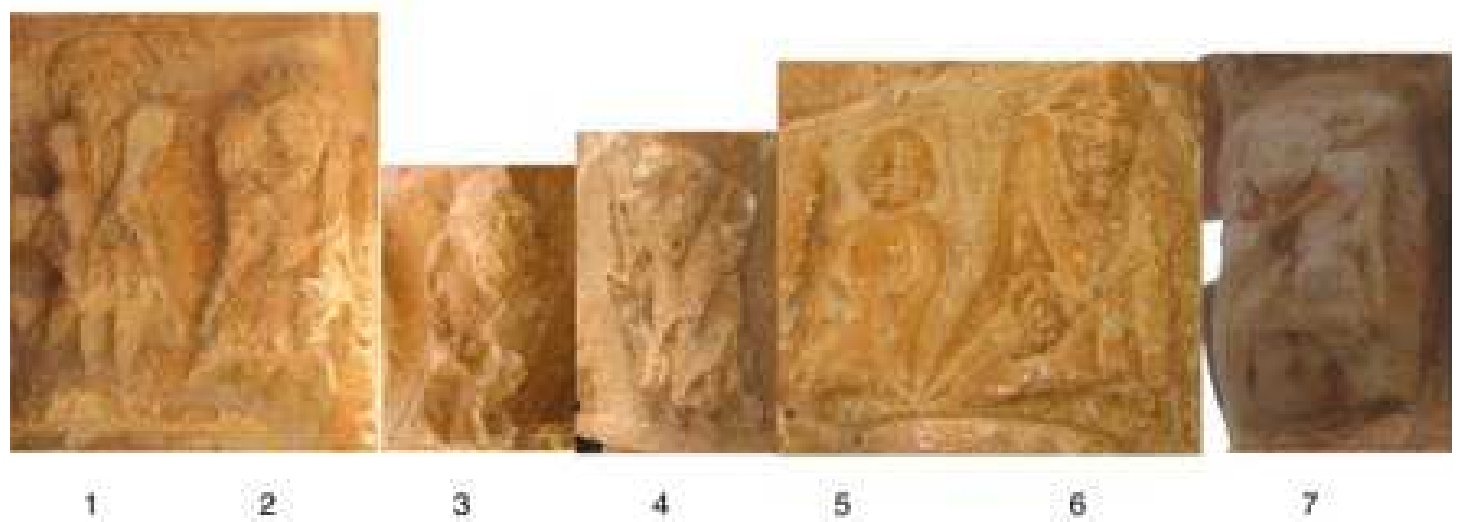

Fig. 4: Programa iconográfico en las Iglesias de San Miguel y de Nuestra Señora del Rivero (San Esteban de Gormaz). (RODRÍGUEZ PÉREZ, Nerea. 2013)

${ }^{31}$ VV.AA. 2002: 866. 
1) ¿Cantante? (Iglesia de San Miguel).

2) Viola con arco sobre hombro. (Iglesia de San Miguel).

3) Viola con arco sobre hombro. (Iglesia de Nuestra Señora del Rivero).

4) Viola con arco sobre hombro. (Iglesia de Nuestra Señora del Rivero).

5) ¿Cantante? (Iglesia de Nuestra Señora del Rivero).

6) Viola con arco sobre hombro. (Iglesia de Nuestra Señora del Rivero)

7) Viola con arco sobre hombro. (Iglesia de Nuestra Señora del Rivero)

\section{Alpanseque}

Iglesia de Nuestra Señora de la Asunción. Arquivolta de la portada del muro sur.

En el muro sur de esta iglesia se descubrió en $1985^{32}$ una puerta que había sido cegada y que actualmente sirve de fondo del cementerio parroquial. Esta entrada tiene una de las portadas más interesantes del románico soriano, sobre todo por la simbología de su tímpano.

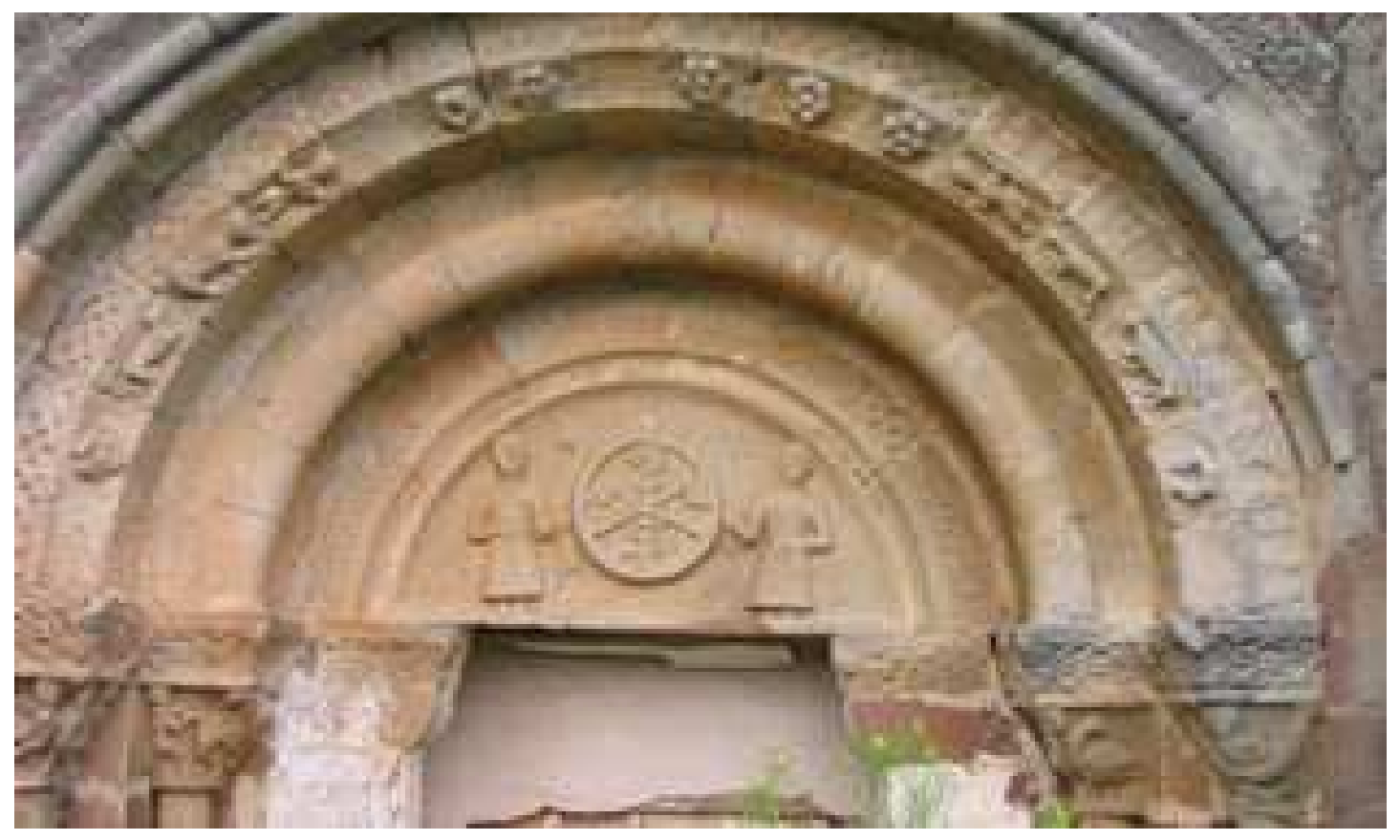

Fig. 5: Portada del muro sur de la iglesia de Nuestra Señora de la Asunción (Alpanseque). (RODRÍGUEZ PÉREZ, Nerea. 2003)

En cuanto a la arquivolta donde localizamos a los personajes, creemos que forma una escena conjunta, mostrando dos de las actividades más frecuentes en esta zona de Castilla: la caza y el pastoreo. El personaje con trompa representa una escena claramente de caza, y el personaje de la derecha, en idéntica posición, lleva, aparte de la lanza, un objeto cilíndrico, que podría ser una flauta, si consideramos ésta como una escena de pastoreo. Es solo una suposición, ya que no podemos afirmar con seguridad que sea un instrumento musical, y mucho menos cogiéndose en posición vertical, pero cabe esa posibilidad al relacionarlo con este oficio.

${ }^{32}$ VV.AA. 2002: 166. 
Nerea RODRÍGUEZ PÉREZ, Iconografía musical en el románico de la provincia de Soria

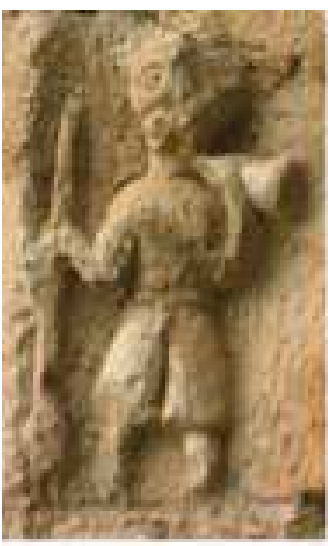

1

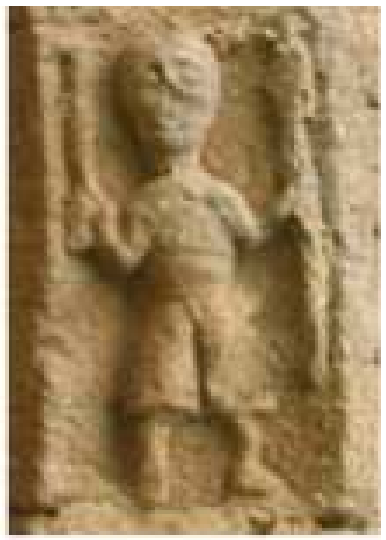

2

Fig. 6: Programa iconográfico en la iglesia de Nuestra Señora de la Asunción (Alpanseque). (RODRÍGUEZ PÉREZ, Nerea. 2013)

1) Trompa.

2) ¿Flauta?

Iglesia de Santo Domingo (Soria). Primera arquivolta de la portada.

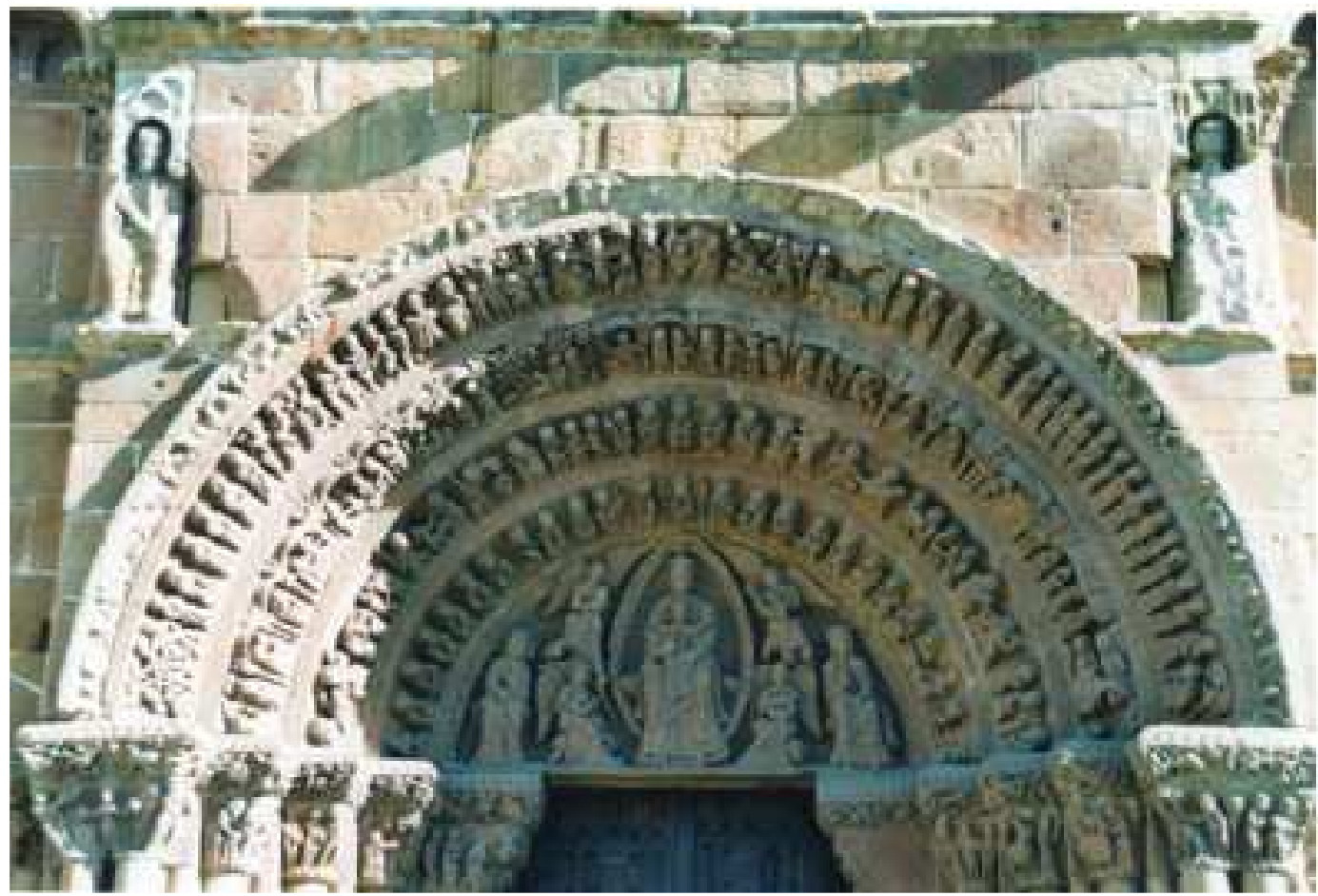

Fig. 7: Portada de la iglesia de Santo Domingo (Soria). (RODRÍGUEZ PÉREZ, Nerea. 2003)

Alrededor del trono había veinticuatro tronos, sobre los que estaban sentados veinticuatro ancianos vestidos de blanco y teniendo sobre sus cabezas coronas de oro... (Apocalipsis IV, 4)

... y los venticuatro ancianos cayeron delante del Cordero, cada cual con su cítara, y copas de oro llenas de perfumes, que son las oraciones de los Santos. (Apocalipsis, $\mathrm{V}, 8)$ 


\section{La iglesia}

Las obras de la iglesia de Santo Domingo se iniciaron en el año 1170. Este es un dato en el que coinciden todos los estudios sobre la iglesia, pero no debemos olvidar que es el comienzo de las obras, por lo que la fachada (la parte que nos interesa), que es lo último que se construye de las iglesias, no puede ser de esta fecha, sino posterior.

En cuanto al motivo de la edificación, parece ser que Alfonso VIII mandó construir la iglesia. Según José María Izquierdo Bertiz ${ }^{33}$, se trata de un tópico admitido, pero sin una base firme. La defensa de la relación entre Alfonso VIII y la iglesia de Santo Tomé, a la cual se acogen muchos estudios, la hace Georgiana G. King en el año $1926 .{ }^{34}$ El artículo de Georgiana G. King pretende demostrar la relación entre Alfonso VIII y la iglesia; sin embargo, no presenta ninguna prueba de peso. No obstante, muchos de los estudios posteriores citan a King como origen de la hipótesis, sin corroborar que lo que dice en realidad es que las dos estatuas que presiden la fachada son los Reyes de Castilla. Se trata de una hipótesis imposible de demostrar, debido al deterioro de las estatuas. Pese a todo, como explicaremos más adelante, se trata de una hipótesis bastante lógica, a la cual aportaremos una nueva vía para la reflexión.

Otros autores ${ }^{35}$, partiendo de esta afirmación, presentan los siguientes argumentos para defender la autoría de Alfonso VIII como promotor de las obras: a) El paso de Alfonso VIII y Leonor de Aquitania por Soria, de camino a Burgos, tras el casamiento en Tarazona en 1170 ; b) Las características peculiares de la fachada, semejante a las construcciones románicas del suroeste francés, especialmente a la iglesia de Notre Dame la Grande de Poitiers; c) Las dos figuras que presiden la fachada, hoy sin rostro y muy deterioradas, que Georgiana G. King presenta, como ya hemos citado, como las imágenes de los Reyes de Castilla; d) La unión que sentía Alfonso VIII con el pueblo soriano, al que demostrará en muchas ocasiones la gratitud de haberle acogido en su niñez.

Como conclusión, es lógico pensar que fue Alfonso VIII quien mandó construir la iglesia de Santo Tomé, al estilo de las iglesias del suroeste francés, en honor a su esposa, pero, aunque es una hipótesis posible, no hay ningún documento escrito que la corrobore.

\section{Reconstrucciones de la iglesia de Santo Domingo en Soria}

En 1884, la Comisión Provincial de Monumentos realiza un informe alarmante sobre el estado casi ruinoso de la fachada de la iglesia. Como consecuencia, se acuerda la reconstrucción y se comienza a trabajar en las vidrieras del rosetón, pero hasta 1917 no se lleva a cabo de manera integral en todo el edificio.

Las obras fueron patrocinadas por el vizconde de Eza, y el arquitecto encargado, Teodoro Ramírez Rojas, acometió los siguientes trabajos: derribo del antiguo coro de los dominicos; reparación de la fachada; desencalo del interior.

La segunda reconstrucción se llevó a cabo entre los años 1990 y 1994 a cargo de la Consejería de Cultura y Turismo de la Junta de Castilla y León, y se centró exclusivamente en la fachada del edificio.

Se hizo un análisis de las lesiones y sus causas, en el que colaboraron distintos expertos de ramas de la investigación científico-técnica. Formaron un equipo de petrólogos, historiadores, biólogos, restauradores y arquitectos.

\footnotetext{
${ }^{33}$ IZQUIERDO BERTIZ 1985: 265-296.

34 KING, G. G. 1926: 3-11.

${ }^{35}$ MARICHALAR 1972; JimÉNEZ GonZALO 1985; GAYA NuÑo 1946 (edición facsímil de 2003).
} 
La degradación de la piedra se debía a la ubicación y orientación de la fachada, expuesta a una climatología extrema y hostil, lo que favorecía la adhesión a la piedra de cristales de yeso.

Los objetivos del equipo de restauración fueron la eliminación de películas y materiales superpuestos, y la consolidación y protección de la fachada. Gracias a estos trabajos podemos estudiar de manera mucho más fiable los elementos escultóricos.

\section{Características de los canteros}

Se identifican dos escultores diferentes en la realización de las figuras, uno de ellos más diestro que el otro. El escultor más hábil es el encargado de casi todas las figuras de las arquivoltas, entre ellas las representaciones de los ancianos. Se aprecia una gran soltura en las representaciones más pequeñas.

Los rasgos que atribuye a las imágenes son: a) en los rostros, cuadrados, ojos almendrados y saltones, cejas finas, comisuras de los labios elevadas (como si sonriera), pómulos salientes y profundas arrugas nasolabiales; b) en las ropas, sensación de telas pesadas con abarrocamiento, propio de finales del siglo XII; lo más característico son las incisiones triangulares que contornean el interior de los pliegues de los ropajes, sobre todo en caderas y espaldas.

Estos rasgos se consideran característicos de muchas obras de Aragón y Burgos de finales del siglo XII.

$\mathrm{Al}$ segundo escultor, considerado menos experto, se le atribuyen algunos capiteles del ciclo del Génesis. Aunque es menos diestro, sigue en lo fundamental al maestro principal. Este es el escultor a quien se relaciona con el maestro de San Juan de la Peña.

De todas formas, y siguiendo la tesis de Inés Ruiz Montejo ${ }^{36}$, los rasgos comunes entre los canteros de esta iglesia y las representaciones en otras iglesias o ermitas son debidos a la influencia común de la Escuela de Santo Domingo de Silos. Es en este monasterio donde se formaron los escultores que desarrollaron su labor artística en Castilla y León, Aragón y Navarra, sobre todo, en las construcciones de orden rural.

En lo que coinciden todos los historiadores que han analizado la fachada de Santo Domingo es en que no se trata de un cantero de procedencia francesa, de maneras mucho más refinadas, y es que, por mucho que queramos defender la calidad de la fachada de Santo Domingo de Soria, hay que reconocer que es de una factura bastante tosca, aunque, eso sí, muy rica en cantidad y contenido.

\section{Programa iconográfico de la primera arquivolta}

De los 25 personajes representados en la primera arquivolta de la fachada de la iglesia de Santo Domingo en Soria, 24 de ellos son los ancianos que cita el Apocalipsis según San Juan. El personaje que completa la escena es un ángel con las alas desplegadas, con un objeto cilíndrico en su mano derecha, que podría ser un incensario.

En esta primera arquivolta aparecen 17 instrumentos musicales, llevados por 18 de los ancianos. Obviaremos a los personajes que portan redomas $\mathrm{u}$ otros elementos no musicales, a excepción del anciano $\mathrm{n}^{\circ}{ }^{\mathrm{o}} 24$, ya que expondremos la posibilidad de que el objeto que sujeta con las manos pueda ser una bolsa y, en sentido musical, una funda de instrumento. Los instrumentos y su descripción es la siguiente:

\footnotetext{
${ }^{36}$ RUIZ MONTEJO 1989: 21-37.
} 

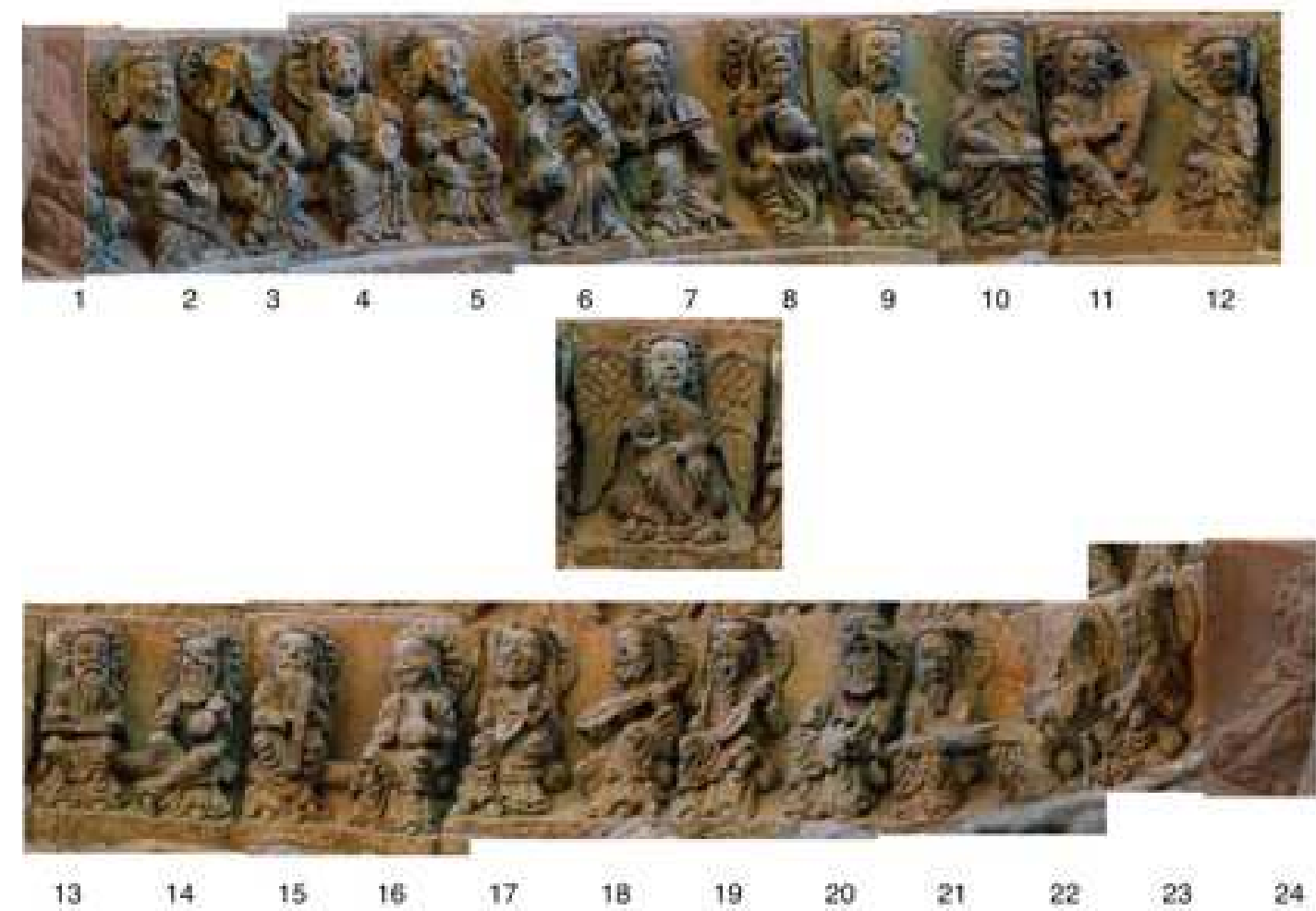

Fig. 8: Programa iconográfico de la primera arquivolta de la portada de la iglesia de Santo Domingo (Soria). (RODRÍGUEZ PÉREZ, Nerea. 2013)

Anciano 2: Viola con arco sobre pierna

Caja acústica: periforme.

Agujeros sonoros: en forma de D.

Mástil: misma pieza que la caja, corto y ancho.

Clavijero y clavijas: en forma romboidal y con solo una clavija (deterioro).

Cuerdas: 2 o 3.

Puente: no.

Cordal: sí.

Cejuela: no.

Arco: se encuentra partido. Curvatura acentuada y de corta longitud.

Anciano 3: Viola con arco sobre hombro

Caja acústica: periforme.

Agujeros sonoros: dos en forma de D.

Mástil: misma pieza que la caja, partido.

Clavijero y clavijas: partido.

Cuerdas: no se puede determinar el número de cuerdas.

Puente: no se observa.

Cordal: sí.

Cejuela: no se observa.

Arco: se encuentra partido. Curvo y largo.

Anciano 4: Viola oval

Caja acústica: periforme.

Agujeros sonoros: dos en forma de D. 
Mástil: misma pieza que la caja, partido.

Clavijero y clavijas: partido.

Cuerdas: no se puede determinar el número de cuerdas.

Puente: no se observa.

Cordal: sí.

Cejuela: no se observa.

Arco: no se representa.

Anciano 5: Viola con arco sobre pierna

Caja acústica: periforme.

Agujeros sonoros: dos en forma de D.

Mástil: muy ancho, misma pieza que la caja.

Clavijero y clavijas: partido.

Cuerdas: tres.

Puente: no se observa.

Cordal: partido.

Cejuela: no se observa.

Arco: curvo, corta longitud.

Anciano 6: Viola con arco sobre hombro

Caja acústica: periforme.

Agujeros sonoros: dos en forma de D.

Mástil: misma pieza que la caja, partido.

Clavijero y clavijas: partido.

Cuerdas: cuatro.

Puente: no se observa.

Cordal: sí.

Cejuela: no se observa.

Arco: curvo. Solo conserva la punta.

Anciano 7: Viola con arco sobre hombro

Caja acústica: periforme.

Agujeros sonoros: dos en forma de D.

Mástil: misma pieza que la caja, partido.

Clavijero y clavijas: partido.

Cuerdas: tres.

Puente: no se observa.

Cordal: sí.

Cejuela: no se observa.

Arco: no muy curvo. Larga longitud.

Anciano 9: Viola oval

Caja acústica: periforme.

Agujeros sonoros: dos en forma de D.

Mástil: misma pieza que la caja, partido.

Clavijero y clavijas: romboidal, no conserva clavijas.

Cuerdas: no se puede determinar el número de cuerdas.

Puente: no se observa.

Cordal: partido.

Cejuela: no se observa.

Arco: no se representa. 
Anciano 10: Salterio con plectros

Caja de resonancia: rectangular.

Aberturas de resonancia: no se aprecian.

Clavijero y clavijas: clavijero situado en la parte frontal del instrumento. Aunque han desaparecido parte de las clavijas, parece corresponder una clavija por cuerda, siendo un total de 18 a 20.

Cuerdas: de 18 a 20.

Cordal: no se aprecia.

Pulsación: por medio de dos plectros de gran tamaño.

Posición: horizontal, sobre las piernas.

\section{Anciano 11: Rota}

Caja de resonancia: contorno triangular. El único lado recto es donde se encuentra el clavijero. El resonador estaría en el lado pegado al cuerpo.

Aberturas de resonancia: no se aprecian.

Clavijero: se encuentra en el lado más corto del triángulo. No se ve, pero se localiza claramente ya que el anciano está manipulando las clavijas para afinar. El clavijero no es lateral. No se puede determinar ni la forma ni el número de clavijas.

Cuerdas: 10 cuerdas, al menos en el lado que se ve. Las cuerdas más cortas son las más cercanas al instrumentista.

Pulsación: utiliza la mano izquierda para pulsar las cuerdas. La digitación empleada es pulgar, índice y medio.

Posición: sentado con las piernas cruzadas. La rota está apoyada entre las piernas.

Otros elementos: llave de afinar en forma de T.

Anciano 12: Viola en forma de ocho

Caja de resonancia: en forma de ocho, misma pieza que el mástil. Tabla armónica plana, el fondo no se aprecia.

Agujeros sonoros: cuatro en forma de D.

Mástil: muy corto y ancho, misma pieza que la caja.

Clavijero y clavijas: clavijero en forma romboidal, con reborde. Dos clavijas.

Cuerdas: no se aprecia el número de cuerdas.

Puente: no se aprecia.

Cordal: sí.

Cejuela: no se aprecia.

Arco: no se representa.

Posición: sobre hombro izquierdo.

Anciano 13: Salterio con baquetas

Caja de resonancia: rectangular.

Aberturas de resonancia: no se aprecian.

Clavijero y clavijas: clavijero situado en la parte frontal del instrumento. Aunque han desaparecido parte de las clavijas, parece corresponder una clavija por cuerda, siendo un total de 22.

Cuerdas: 22.

Cordal: cuerdas atadas a los lados más largos del rectángulo.

Pulsación: por medio de dos baquetas, una más larga que la otra.

Posición: horizontal, sobre las piernas.

Anciano 15: Arpa 
Caja de resonancia: triangular, sin decoración, con una pieza en el ángulo inferior que sirve de unión a dos de los lados, uno de ellos, el frontal con adornos circulares (tipo botones).

Aberturas de resonancia: no se aprecian.

Clavijero y clavijas: el clavijero parece ser una pieza colocada en la parte superior de la caja de resonancia; está muy deteriorado. Las clavijas han desaparecido, pero por la forma de la fractura de la piedra podemos decir que se colocan de manera lateral.

Cuerdas: 20.

Pulsación: con las dos manos, la digitación empleada en pulgar, índice y medio.

Posición: vertical, apoyado entre las piernas.

Anciano 17: Viola con arco sobre pierna

Caja acústica: periforme.

Agujeros sonoros: dos en forma de D.

Mástil: misma pieza que la caja.

Clavijero y clavijas: forma romboidal con tres clavijas.

Cuerdas: tres.

Puente: no se observa.

Cordal: sí.

Cejuela: no se observa.

Arco: de corta longitud, curvo y roto en la punta.

Anciano 18: Viola con funda

Caja acústica: periforme.

Agujeros sonoros: dos en forma de D.

Mástil: dentro de la funda.

Clavijero y clavijas: dentro de la funda.

Cuerdas: tres.

Puente: no se observa.

Cordal: sí.

Cejuela: no se observa.

Arco: no se representa.

Otros elementos: funda.

Anciano 19: Viola con arco sobre pierna

Caja acústica: periforme, con los hombros más marcados.

Agujeros sonoros: dos en forma de D.

Mástil: misma pieza que la caja.

Clavijero y clavijas: romboidal, con dos clavijas.

Cuerdas: no se puede determinar el número de cuerdas.

Puente: no se observa.

Cordal: sí.

Cejuela: no se observa.

Arco: largo, con poca curvatura.

Ancianos 21, 22: Organistrum

Caja de resonancia: forma de ocho, tabla armónica y fondo plano.

Aberturas de resonancia: 4 en forma de D.

Mástil: gran deterioro, partido.

Rueda, manivela: la rueda no se aprecia, la manivela se encuentra en la parte inferior del instrumento. 
Puente: no.

Cuerdas: número sin determinar.

Cordal: sí, en la parte inferior.

Posición: vertical, sobre el regazo de dos ancianos: uno acciona las teclas (que no se aprecian por el deterioro) y el otro acciona la manivela.

\section{Anciano 23: Viola con arco sobre pierna}

Caja acústica: periforme.

Agujeros sonoros: no se observan.

Mástil: misma pieza que la caja, partido.

Clavijero y clavijas: muy deteriorado.

Cuerdas: no se puede determinar el número de cuerdas.

Puente: no se observa.

Cordal: no se observa por el gran deterioro.

Cejuela: no se observa.

Arco: corta longitud y muy curvo.

\section{Anciano 24: Bolsa o pliegue}

La ya mencionada influencia silense nos lleva a comparar a los ancianos de la iglesia de Santo Domingo con los de la iglesia de Nuestra Señora de la Asunción en Ahedo de Butrón (Burgos). Ambas iglesias representan a los Veinticuatro Ancianos del Apocalipsis y ambas coinciden, entre otros muchos aspectos, en que cuentan con un anciano que saca una viola de una funda y otro anciano que lleva en sus manos un posible trozo de tela. $\mathrm{Si}$ todos los personajes de estas dos representaciones tienen una función musical o de portadores de redomas, ¿qué función damos a estos dos ancianos que portan algo parecido a una tela? Si les damos un sentido musical, esta tela podría ser una funda de instrumento; si no se lo damos, son personajes que no tienen ninguna relación con el programa iconográfico. Así que planteamos la posibilidad de que puedan ser fundas de instrumentos.
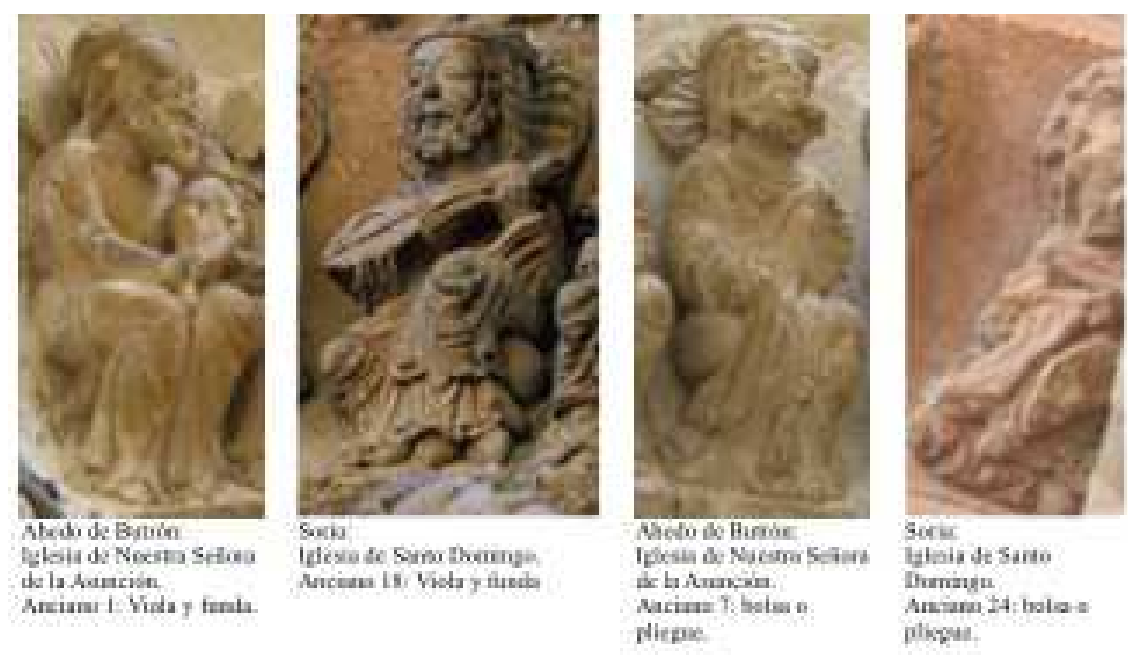

Fig. 9: Ejemplos de fundas y posibles bolsas en la representación de los Veinticuatro Ancianos del Apocalipsis. (RODRÍGUEZ PÉREZ, Nerea. 2013)

\subsection{Catálogo de elementos musicales}

De las 59 escenas musicales localizadas en el románico soriano, la familia con más presencia es la de los cordófonos, y, principalmente, los de cuerda frotada. Le siguen los aerófonos, con prevalencia de las trompas de carácter pastoril o de caza. Las escenas de 
cantores quedan entre interrogaciones, al igual que alguno de los aerófonos, tal y como señalaré en el análisis por familias. En último lugar quedan los membranófonos, con una sola representación también muy dudosa.

\subsubsection{Cordófonos}

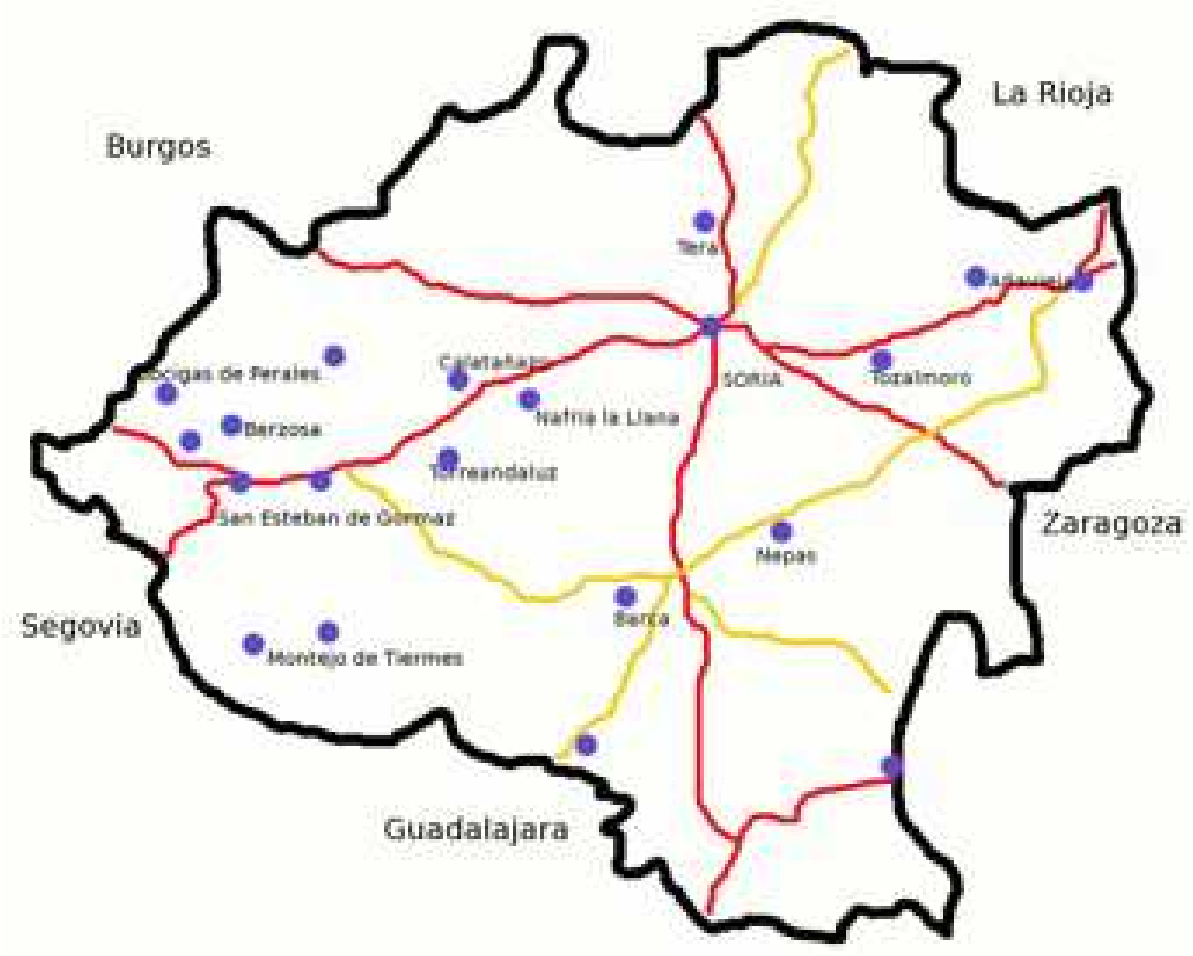

Fig. 10: Mapa de todas las localidades sorianas con imágenes de cordófonos en su románico. (RODRÍGUEZ PÉREZ, Nerea. 2013)

Trece son las localidades que tienen algún tipo de instrumento de cuerda, con un total de 36 representaciones. La fuente más importante, como acabamos de explicar, es la de Soria capital, con la representación de los Veinticuatro Ancianos del Apocalipsis según San Juan.

La relación de los cordófonos localizados en el románico de la provincia de Soria es la siguiente:

\section{Violas con arco}

Es el grupo más numeroso, con 24 fuentes analizadas. Podemos comprobar lo heterogéneo de las tallas, tanto con respecto a la conservación como a la elaboración y a la fidelidad con modelos más o menos elaborados. Abundan la desproporción de tamaños y la falta de precisión. Casi todos ellos están localizados en canecillos y capiteles, y solo en Santo Domingo de Soria, en la arquivolta de una portada. 
Nerea RODRÍGUEZ PÉREZ, Iconografía musical en el románico de la provincia de Soria

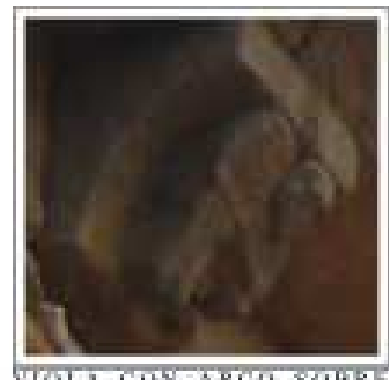

YTOLA CONARCO SOBR: HOMano

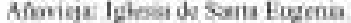
Cuncelo de t a save (2in)

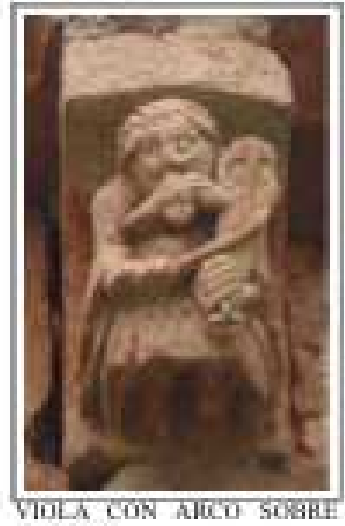

Hoмaro

Moncio de Vorace Emm

de Sarta Mroia ils Tremes

Ciencills ilnde. (2006)

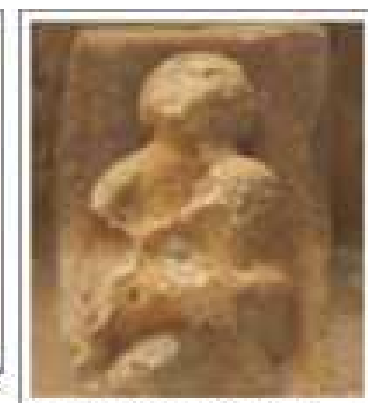

VOLACONATCOSOBRE BOSIBRO

Bava: Iflesia de Sans Cratira. Ceaecillo polerie porticads f20nsi

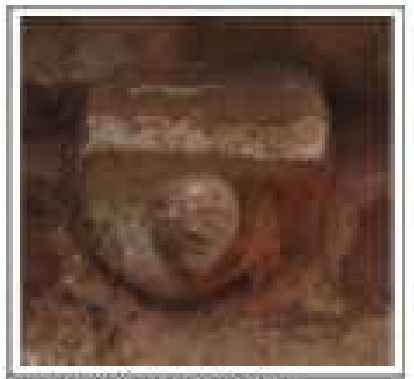

VICX.ACONARCOSOER: Homatio

Montejo de Thermes Ermita

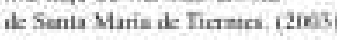

2003

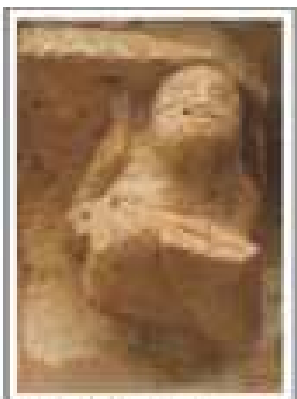

VIOLACONAIICO

Bews: Ifloiale Satia

Cristims.

Cancillo gobria porticada

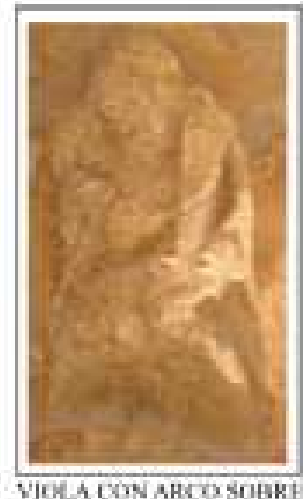

HOMARO

San Estchas de Gumme

Iglesa dé Sal Mipuel

Capitil galata purticalu (2503)

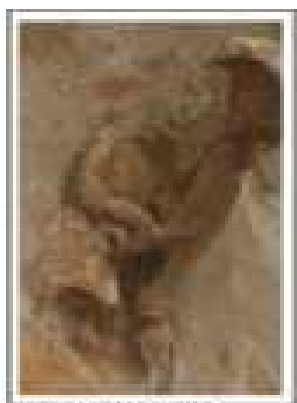

VOLA CON ARCO

SXHRE HOMBSO

Bociges de Rerakes:

Idesis de San Fedio atatibu staikle 12603)
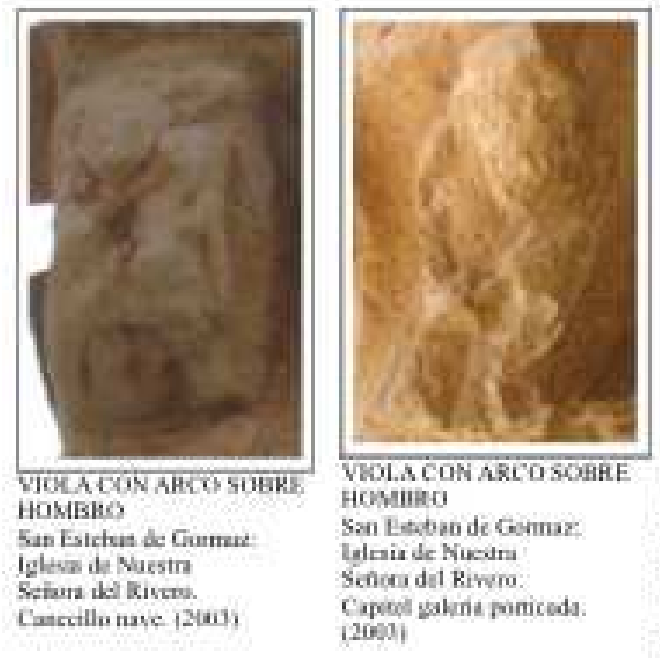

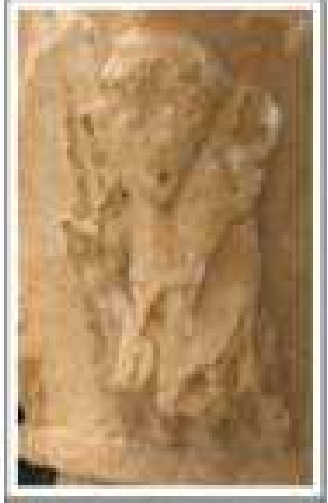

TOLLACON ARCOSCARB HOMARO

San Blchan de Cammé

Iglexia de Niesin

Secome del Risero

Cupilt elcria puticala $12 \tan 3$

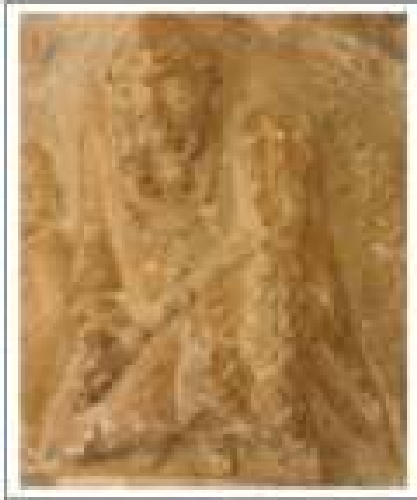

VIOLLA CON ABCO SOQRE HOMILRO San Etabas de Gamar:

Igleso de Nacim

Setivita del Rivetu

Capited calosis purticaits. $[2(0))$

Fig. 11.1: Violas con arco. Iglesias románicas de la provincia de Soria.

(RODRÍGUEZ PÉREZ, Nerea. 2003) 
Nerea RODRÍGUEZ PÉREZ, Iconografía musical en el románico de la provincia de Soria

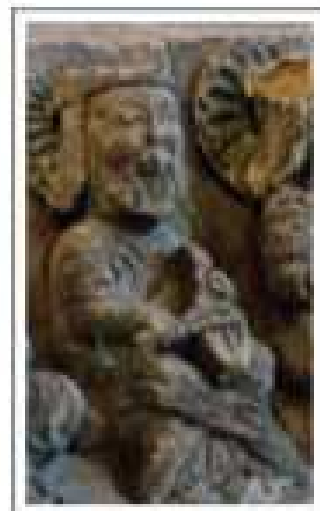

VIOLA CON ARCO SOARE PIERNA

Saria: Jglesia de Santo Domingo

Primera arquivolta portadi Ancimo 2 (2003)

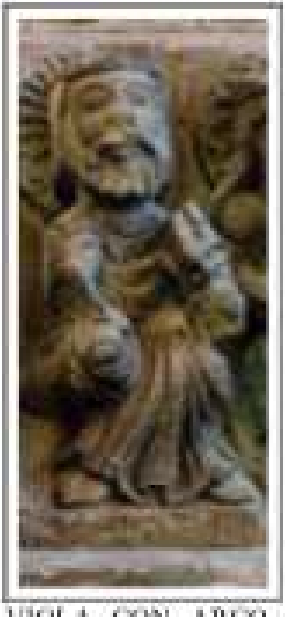

VIOLA CON AREO SOARE HOMHRO

Saria Ialvsia de

Santo Domingo Primera arquivols portade Anciane $f$. (2003)

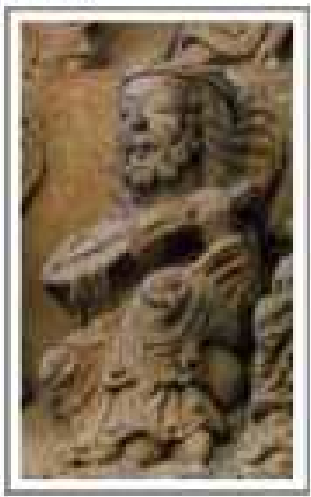

YIOIACON FUNDA

Soeta: iglesin se

Santo Dominga Primer

arquivolita portada Anciano

18. 120013

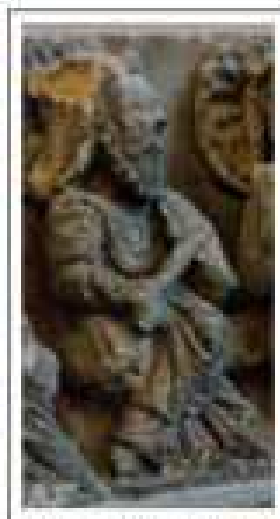

VIOLA CON ARCO SOBRE HOMBRo

Soria: Iflexis de

Santo Domingo, Primera anquivola portada Ancieno 3 |2007\}

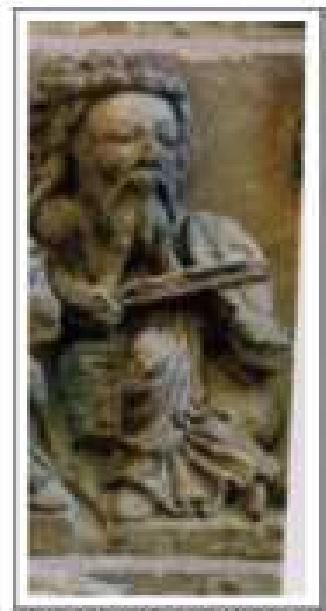

VIOLA CON ARCO SOFRE HOMBRO

Soria: Iglesia de Samto Donwingo.

Primera arquivolta portada

Anciats T. (2003)

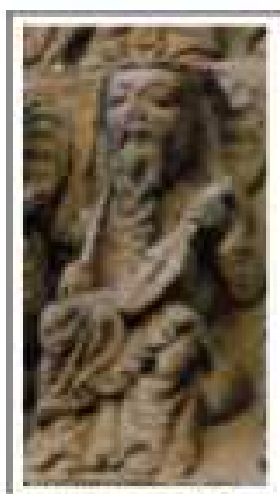

VOLA CON ARCO SOBRE PIERNA

Soria Tzlesia de

Santo Domingo. Primera arywiyolia portado Anciano 19. \{2003)

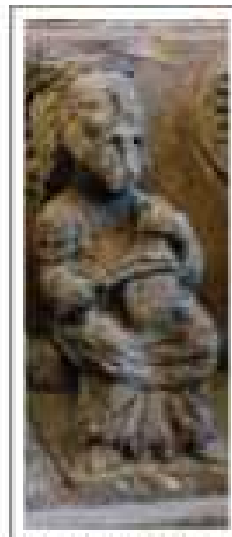

VIOLA CON ARCO SOBRE MERNA

Sonia: lalesia de

Sonto Domingo Primar ntquivolia portad Anciade 3. \{20053\}

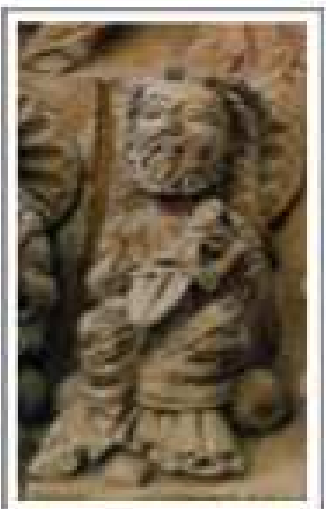

VOLA CON ARCO SOBRE PIERNA

Sorie: Itrlusia de

Sasto Domingo Primera urquivalta portada Anciemo 17. (2003)

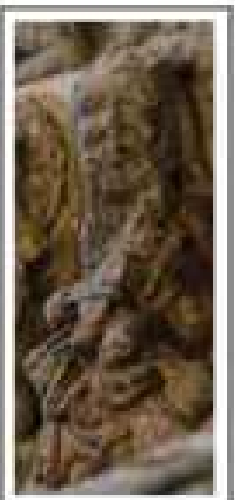

NIOLA CON ARCD SOBRE PIFRNA

Sarie Flesia de

Santo Domingo. Primera arquivelta poetads Asciane 23. (20063)

Fig. 11.2: Violas con arco. Iglesias románicas de la provincia de Soria

(RODRÍGUEZ PÉREZ, Nerea. 2003) 
Nerea RODRÍGUEZ PÉREZ, Iconografía musical en el románico de la provincia de Soria

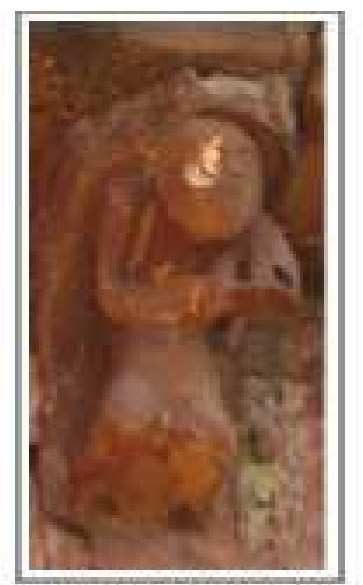

VIOLA SOERE HOMBRO

Tera: Izlesia de Nuestra

Sctoen del Cammen.

Casecillo athide (2005)

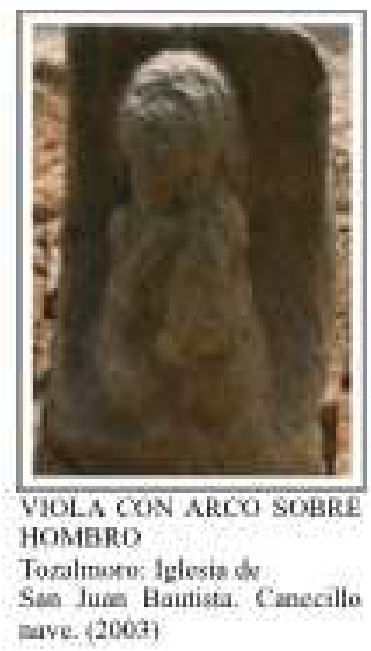

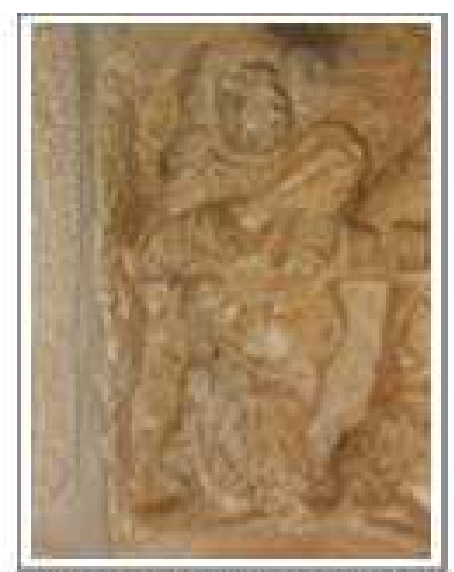

VIOLA CON AKCO SOBRE HOMBRO

Turretablatuz: Iglesia de

Santo Domingo te Silos Capinel portala. \{2007\}

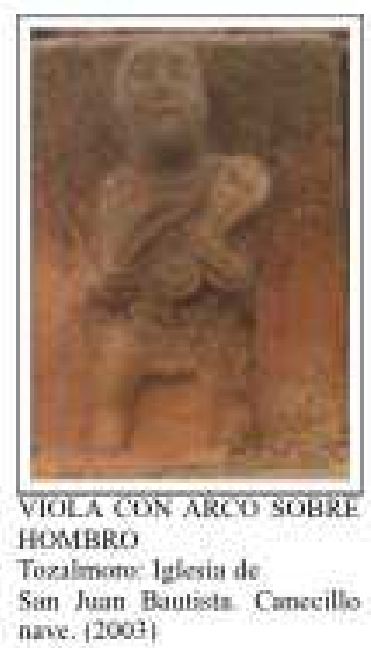

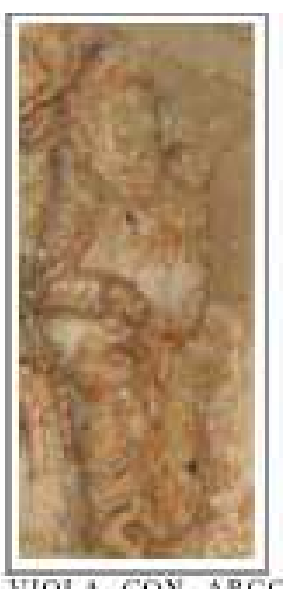

CON ARCI SOBRE PIERNA

Torreanduluz lestesia de

Sacoso Daminge de Sillos. Caputel porada (201) i)

Fig. 11.3: Montaje violas con arco. Iglesias románicas de la provincia de Soria. (RODRÍGUEZ PÉREZ, Nerea. 2003)

Violas ovales sin arco

Las dos fuentes pertenecen al conjunto de la iglesia de Santo Domingo. Al tener ambos personajes en la mano derecha la citada redoma de la Biblia, no podemos saber si estos instrumentos se tañían con arco o con plectro, aunque da la impresión de que son instrumentos de arco. En ninguno de los dos instrumentos se representa puente, necesario en los instrumentos de cuerda pulsada. Pero esto no es concluyente, ya que pueden no ser representaciones exactas de los instrumentos reales de la época. 
Nerea RODRÍGUEZ PÉREZ, Iconografía musical en el románico de la provincia de Soria

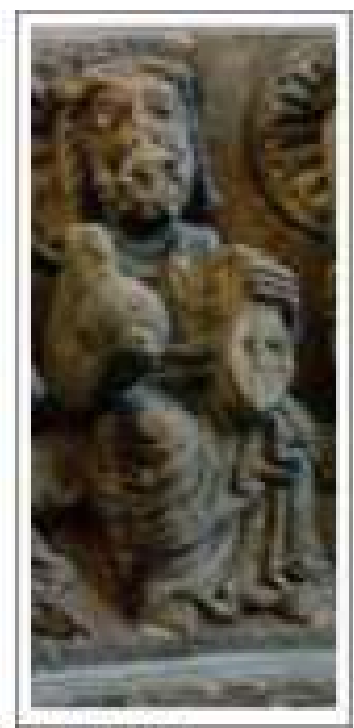

WHLA HWL

Smiz labsin

4um Lhminh

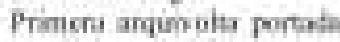

Hichind 4 IIHT)

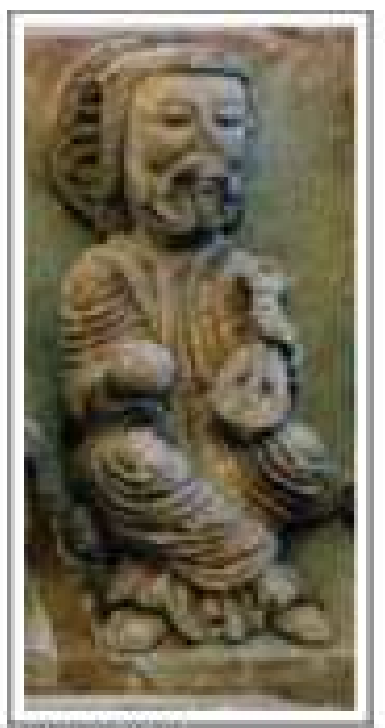

VNII LWH

Gure Lisale

Sinis Domitn Proict

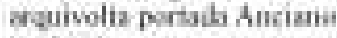

i1 (IIH)

Fig. 12: Violas ovales. Iglesias románicas de la provincia de Soria. (RODRÍGUEZ PÉREZ, Nerea. 2003)

\section{Viola en forma de ocho ${ }^{37}$}

Solo tenemos esta fuente claramente basada en el modelo de viola oval, aunque por duplicado. Lo podemos observar en el raro hecho de tener cuatro agujeros resonadores en vez de dos.

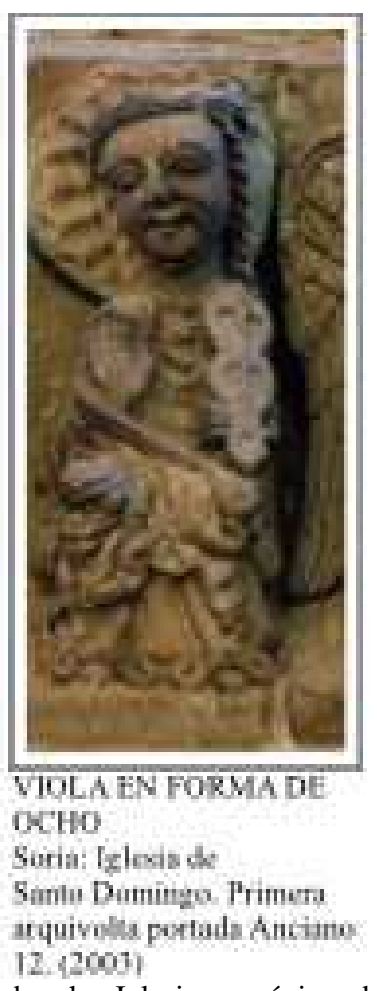

Fig. 13: Viola en forma de ocho. Iglesias románicas de la provincia de Soria. (RODRÍGUEZ PÉREZ, Nerea. 2003)

37 Según Christian Rault podemos citar este instrumento como "Giga". Véase: www. Christianrault.com/sp/publicaciones “La gigue: l'autre vièle médiévale?” París, 2001. 


\section{Rotas}

Considero estos instrumentos rotas, y no arpas, por tener el clavijero en la parte superior y las clavijas en sentido paralelo a las cuerdas; la tabla armónica estaría en la parte que no podemos ver. En la de Santo Domingo aparece también una llave de afinar en forma de $\mathrm{T}$, que el músico sujeta en la mano derecha. También parece utilizar los dedos pulgar, índice y medio de la misma mano.
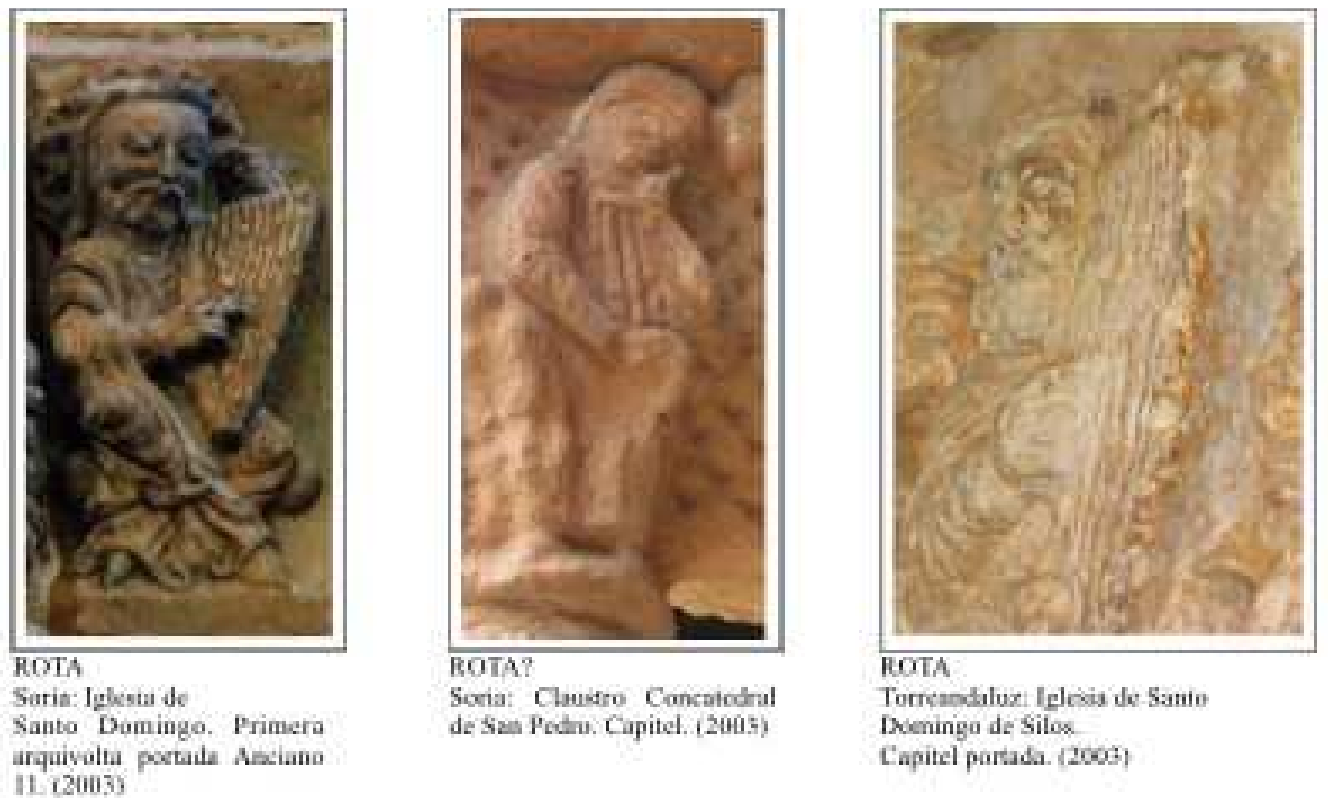

Fig. 14: Rotas. Iglesias románicas de la provincia de Soria. (RODRÍGUEZ PÉREZ, Nerea. 2004)

Arpas

Tenemos solo dos ejemplos, y son dos representaciones muy diferentes entre sí, claramente copiadas de modelos diferentes. En lo que coinciden los instrumentistas es en el uso de los dedos índice y medio para pulsar las cuerdas.
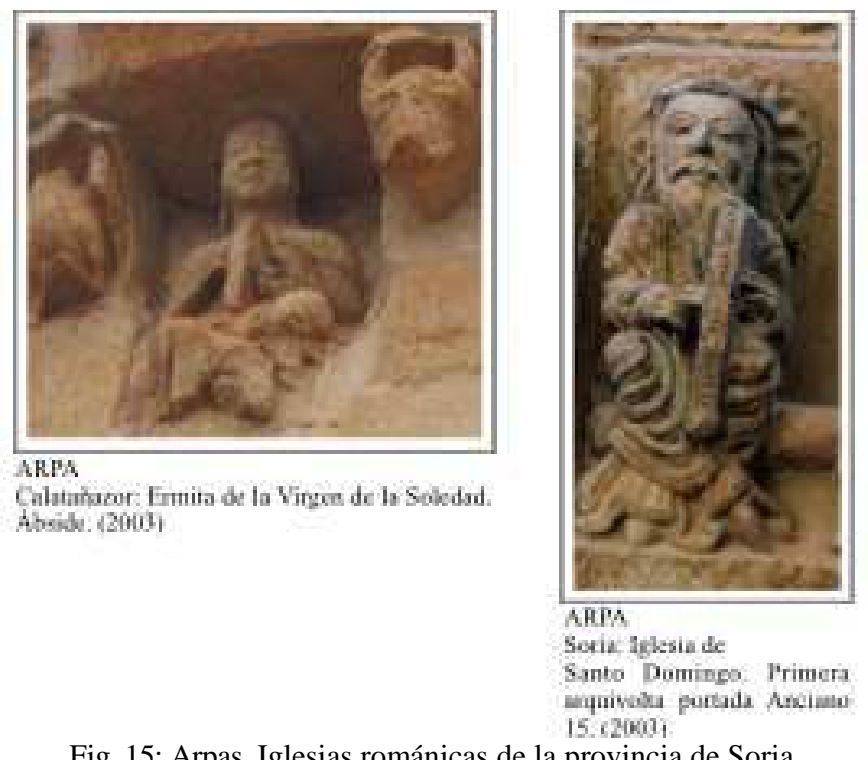

Fig. 15: Arpas. Iglesias románicas de la provincia de Soria. (RODRÍGUEZ PÉREZ, Nerea. 2003)

\section{Salterios}

Los dos instrumentos pertenecen a la fuente de la iglesia de Santo Domingo. Vemos las dos formas diferentes de interpretar este instrumento, con baquetas y con plectros. 
Nerea RODRÍGUEZ PÉREZ, Iconografía musical en el románico de la provincia de Soria

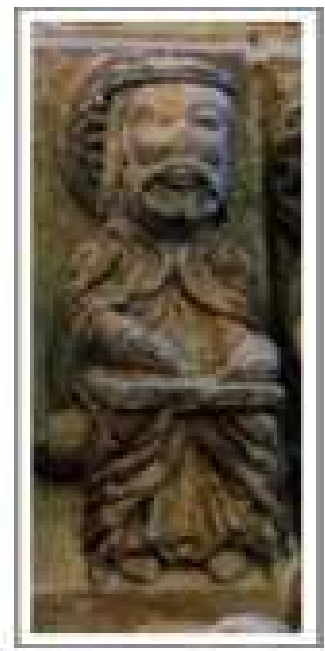

SNLTERE

Seriz: Ielesin de

Somo Domingo. Reimera

arquivoles poriada

Axcians $10 .(200,4)$

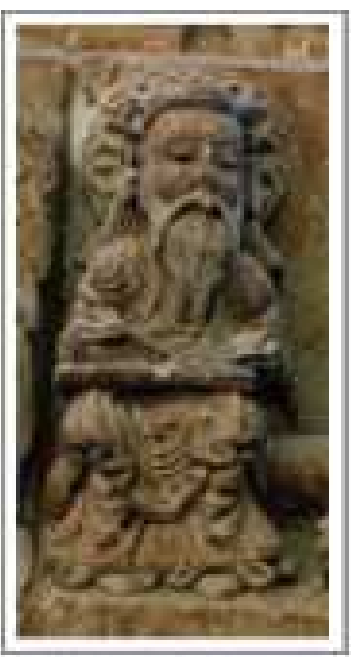

SALTERIO

Somia lelesia de.

Sants Doekingo. Printers

aquivolis portade Aricine

13. $\{2003\}$

Fig. 16: Salterios. Iglesias románicas de la provincia de Soria. (RODRÍGUEZ PÉREZ, Nerea. 2003)

\section{Tipo laúd}

Claramente estos instrumentos son de cuerda pulsada, mástil y clavijero al final. En el caso del instrumento de Torreandaluz, la caja es periforme y está en posición de tocar. El de Nafría la Llana se encuentra en un lamentable estado de conservación.
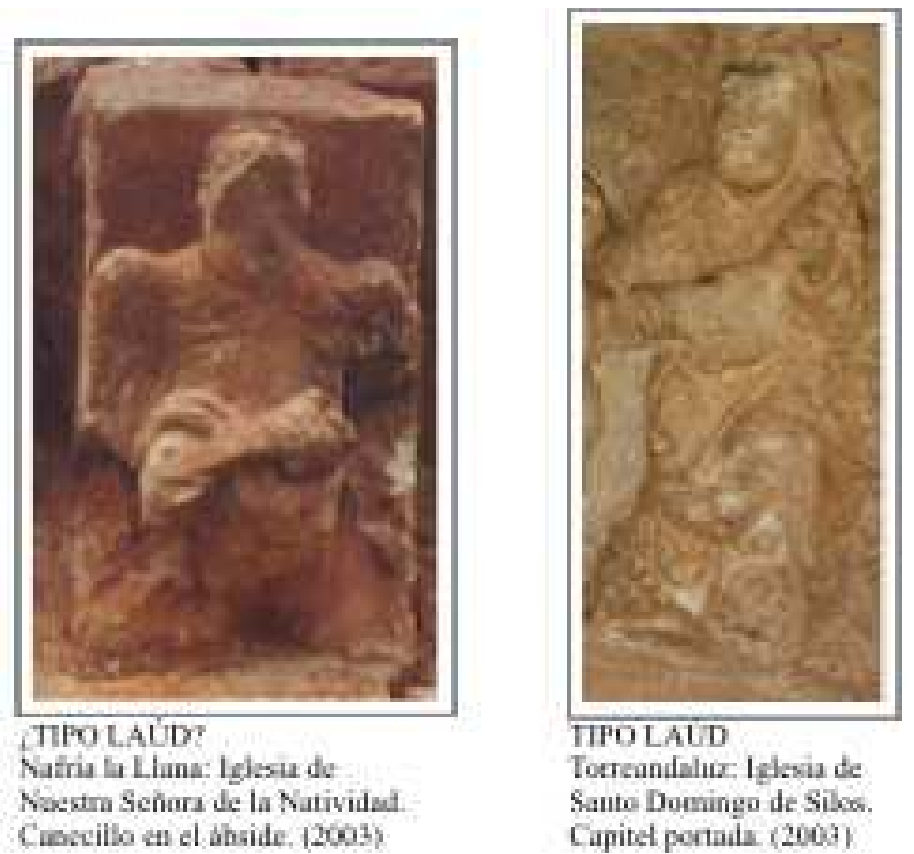

Fig. 17: Tipo laúd. Iglesias románicas de la provincia de Soria. (RODRÍGUEZ PÉREZ, Nerea. 2004)

\section{Organistrum}

Este organistrum está tañido por dos de los ancianos, uno encargado de la manivela que mueve el rodillo interior, y el otro, muy dañado, encargado de las pequeñas palancas o teclas que servían para acortar las cuerdas melódicas. 
Nerea RODRÍGUEZ PÉREZ, Iconografía musical en el románico de la provincia de Soria

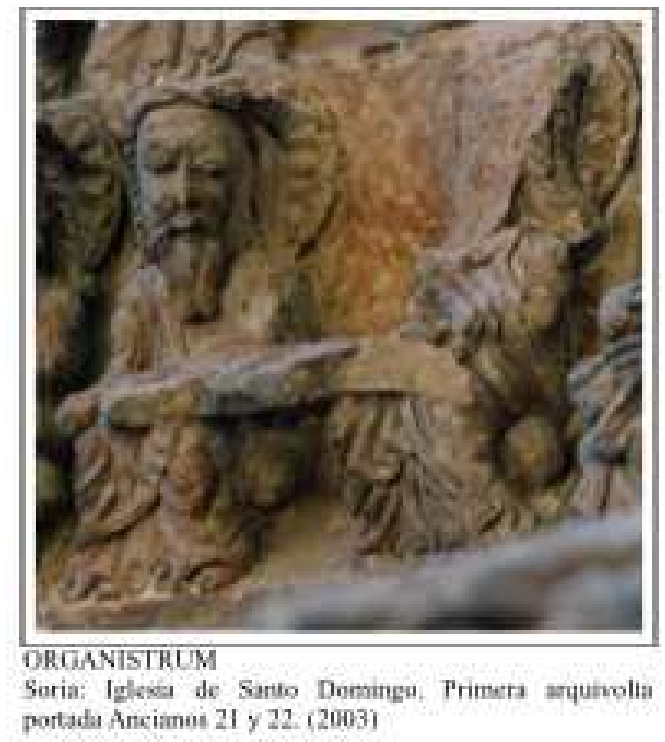

Fig. 18: Organistrum. Iglesias románicas de la provincia de Soria. (RODRÍGUEZ PÉREZ, Nerea. 2003)

\subsubsection{Aerófonos}

Son 12 las localidades que poseen fuentes iconográficas donde se representa algún tipo de instrumento de viento, sumando un total de 16 representaciones. El tipo más usual es la trompa, ya que acompaña con frecuencia escenas de caza o pastoriles. Como en el resto de representaciones, se trata de una escultura por lo general muy tosca, por supuesto, con la excepción de la escena encontrada en la sala capitular de la Catedral de Santa María en El Burgo de Osma.

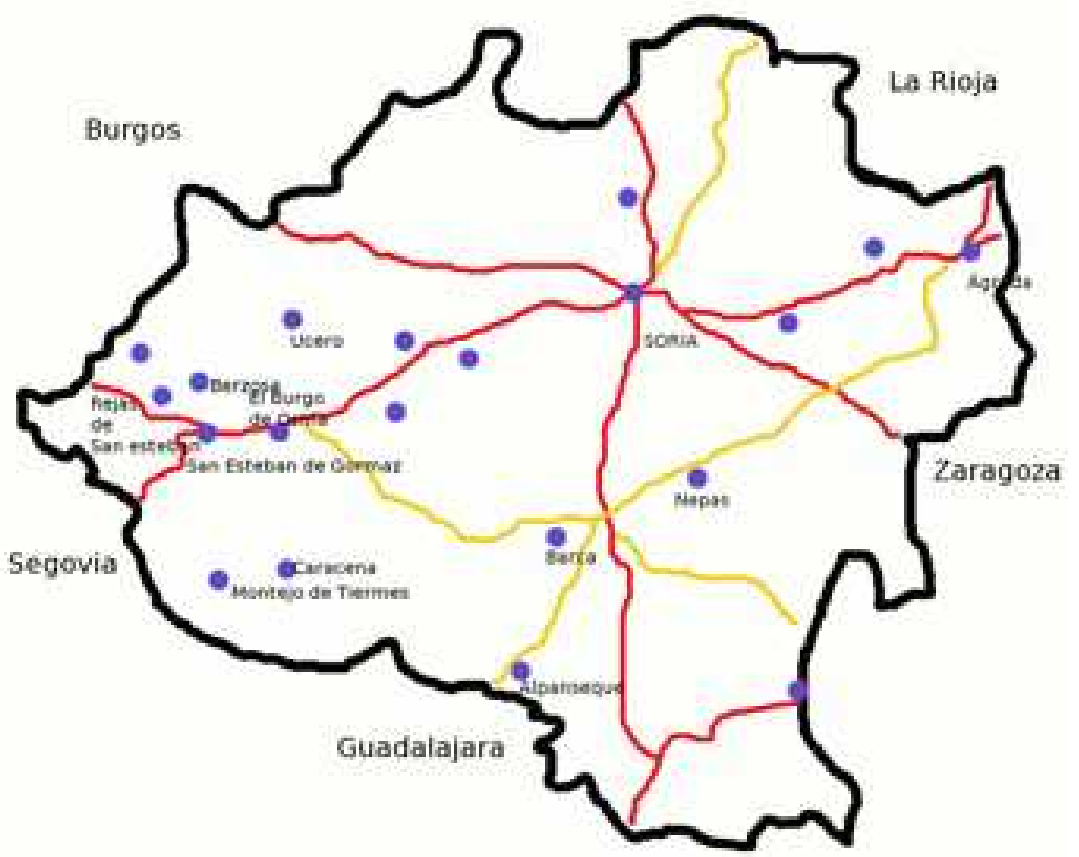

Fig. 19: Mapa de todas las localidades sorianas con imágenes de aerófonos en su románico. (RODRÍGUEZ PÉREZ, Nerea. 2013)

\section{Flautas dulces}

Consideramos flautas dulces a las representaciones de instrumentos de tubo cilíndrico, recto, con agujeros digitales y tocado de manera frontal por medio de un bisel. El bisel es 
imposible de percibir, pero el resto de características son bastante claras, al menos en dos de estas tres representaciones. En el caso de Alpanseque nos enfrentamos ante una duda más que razonable. Este personaje forma parte de un conjunto escultórico formado por unos animales y otro personaje en idéntica posición y fisonomía que lleva una trompa y una lanza. Esto y la posición en "o" de los labios me ha llevado a incluir esta imagen como flauta, aunque es indudable la posibilidad de que no lo sea, quedando así entre interrogaciones, tal y como se ha explicado en el capítulo de "Programas iconográficos".
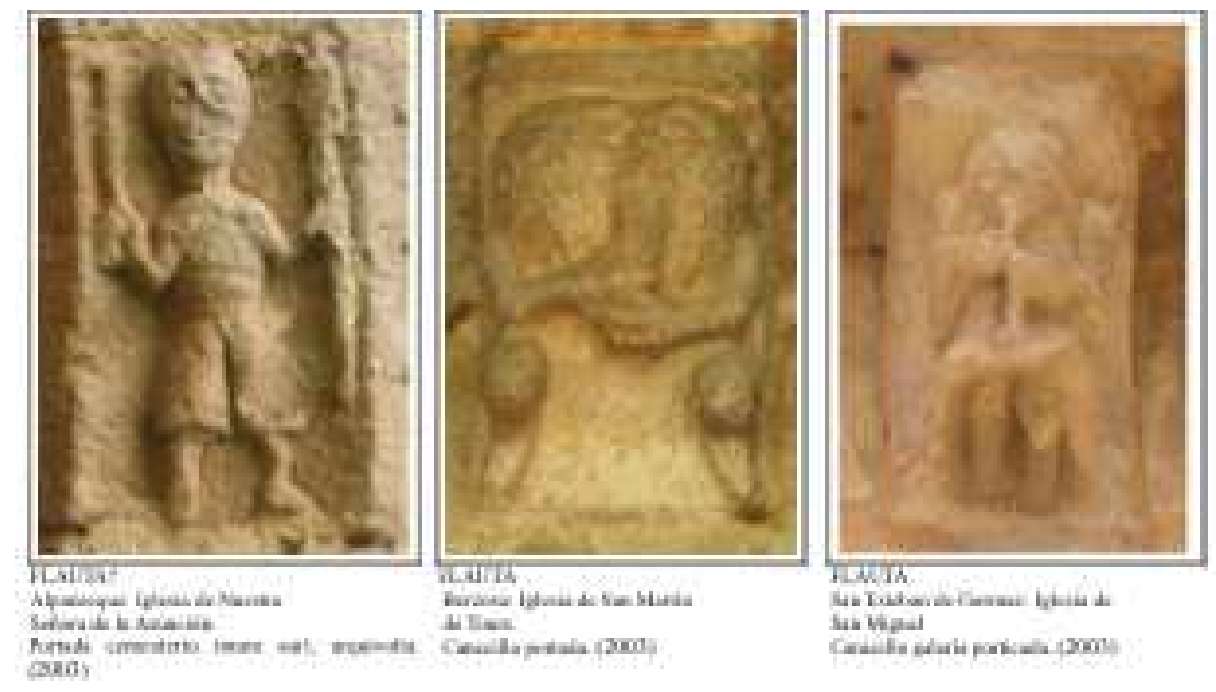

Fig. 20: Flautas dulces. Iglesias románicas de la provincia de Soria. (RODRÍGUEZ PÉREZ, Nerea. 2003)

\section{Aerófonos de tubo recto}

De estas tres representaciones la más peculiar es la de San Esteban de Gormaz, ya que se trata de un instrumento de dos tubos con agujeros digitales que acaban en un mismo pabellón: es muy similar a la tipología del "albogue". No podemos concretar cómo es la embocadura, ni si los dos tubos confluyen en dicha embocadura o son tubos independientes.
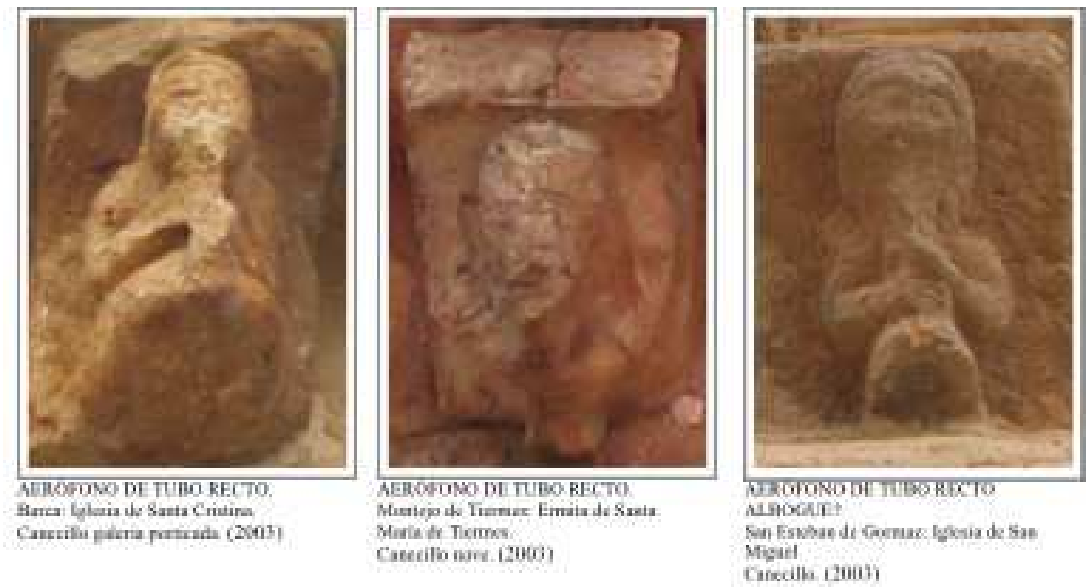

Fig. 21: Aerófonos de tubo recto. Iglesias románicas de la provincia de Soria. (RODRÍGUEZ PÉREZ, Nerea. 2003)

\section{Trompas}

Son un total de siete trompas, siendo la más dudosa de todas la de la iglesia de San Martín de Tours en Berzosa. El hecho de sujetar el instrumento con la mano derecha o la mano izquierda, así como el tañerla de forma frontal o lateral, se debe a razones meramente escultóricas, no musicales. 
Nerea RODRÍGUEZ PÉREZ, Iconografía musical en el románico de la provincia de Soria

Los únicos personajes en posición diferente al resto son el de Berzosa, ya comentado, y el de El Burgo de Osma, ${ }^{38}$ en posición de adoración al niño Jesús. Podemos encontrarlo en la Sala Capitular de la Catedral.
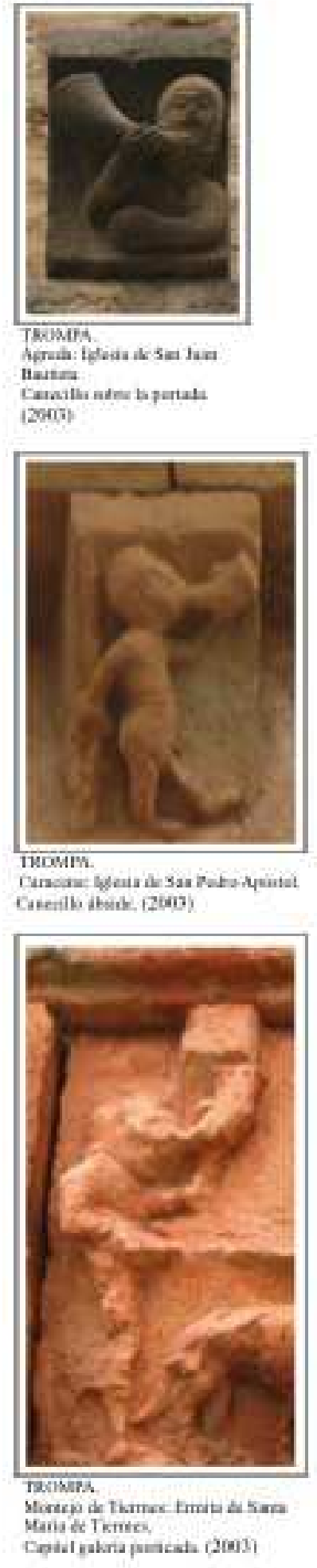

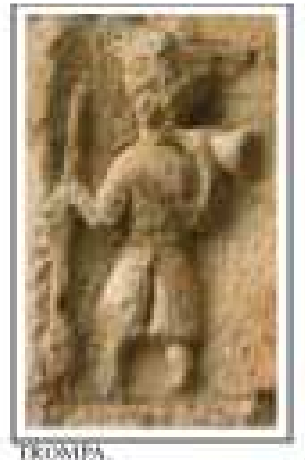

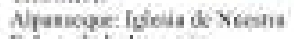
Pustala cascnitrie tman an,

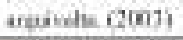
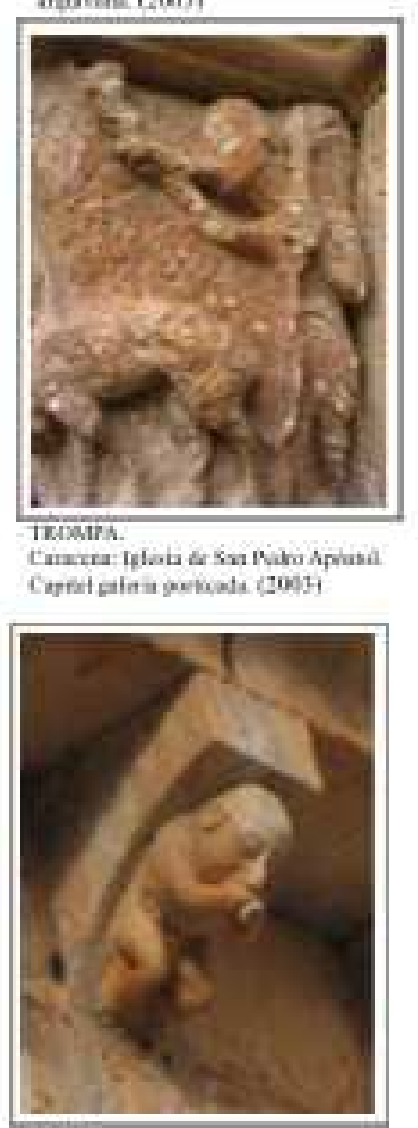

Thostir.

Uane fram \& Sas tlanaker.

Conocile pernok 120133
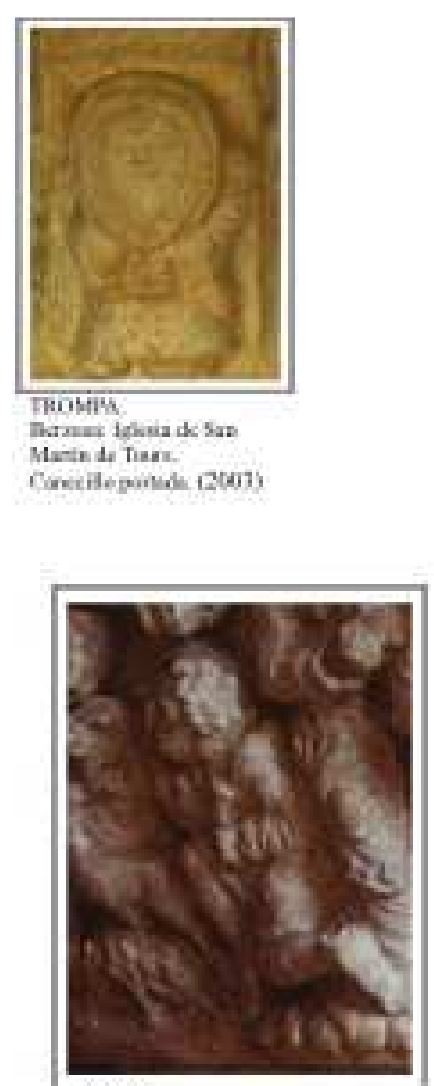

Timasira

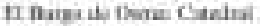

Ae Sisia Mani.

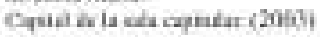

Fig. 22: Trompas. Iglesias románicas de la provincia de Soria. (RODRÍGUEZ PÉREZ, Nerea. 2003)

${ }^{38}$ La imagen pertenece a: "Capitel de la Infanta. Siglo XII Anunciación pastores y adoración Reyes. Catedral El Burgo de Osma", Editado por Trebolfoto, Madrid. 
Nerea RODRÍGUEZ PÉREZ, Iconografía musical en el románico de la provincia de Soria

\section{¿Gaita?}

Esta es una de las escenas más dudosas de la catalogación, por lo erosionado de la piedra y lo esquemático de la imagen. Podemos apreciar dos tubos, siendo el superior el que pasa bajo el brazo, donde estaría el fuelle.

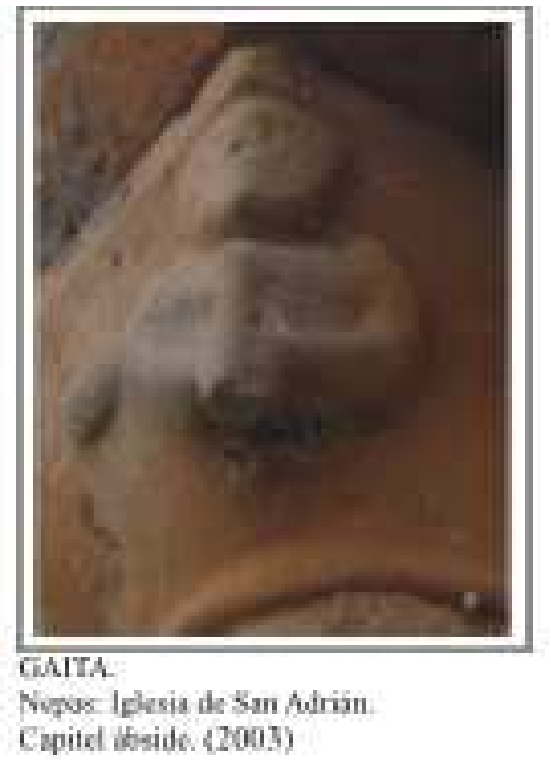

Fig. 23: Montaje gaita. Iglesias románicas de la provincia de Soria.

(RODRÍGUEZ PÉREZ, Nerea. 2003)

\subsubsection{Membranófonos}

Solo tenemos una imagen de este tipo de instrumentos. Además, el mal estado de la figura no nos permite afirmar categóricamente que se trate de un instrumento de percusión.

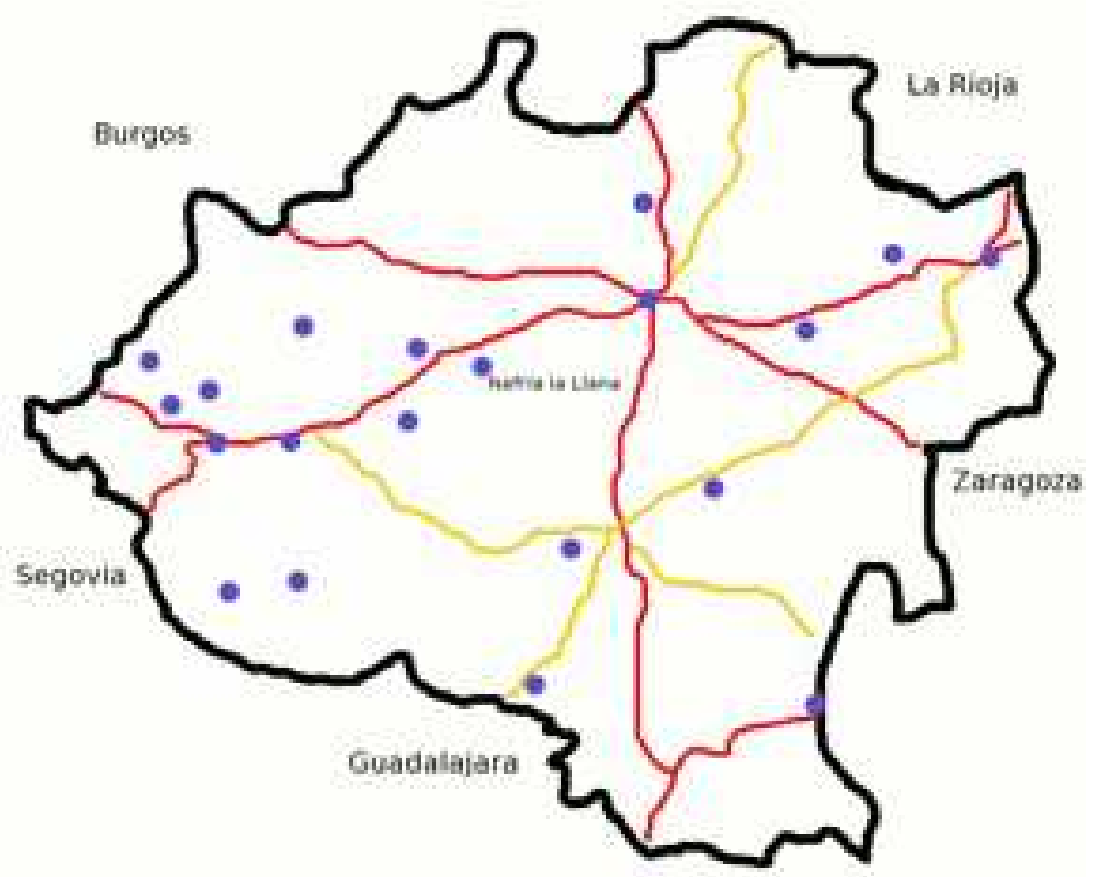

Fig. 24: Mapa de todas las localidades sorianas con imágenes de membranófonos en su románico. (RODRÍGUEZ PÉREZ, Nerea. 2013) 


\section{¿Tambor?}

Posible instrumento de percusión de un solo parche. No podemos dar más información sobre esta fuente, sino solo intuir, por la posición de los brazos, que las desaparecidas manos llevaran unas baquetas para golpear el parche o que golpeara directamente con las manos. Además, la cinta que atraviesa el pecho del instrumentista hace pensar que posiblemente sirviera para llevar el instrumento atado. Aun así, no podemos asegurar que se trate de un objeto musical frente a otro objeto en forma cilíndrica.

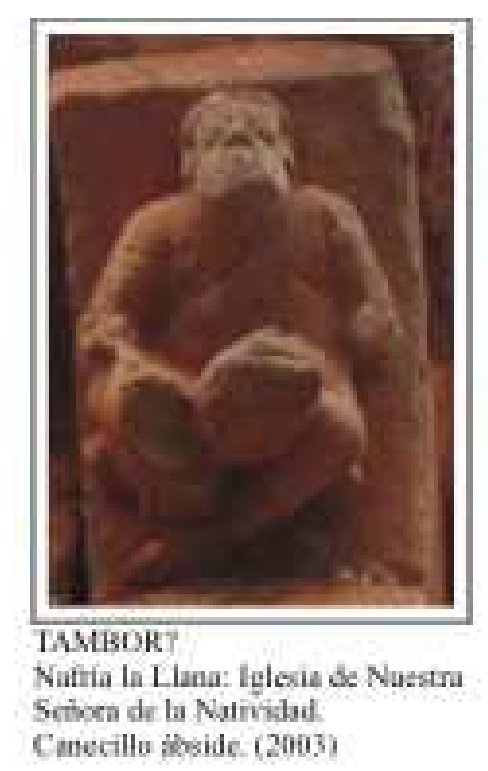

Fig. 25: ¿Membranófono? Iglesias románicas de la provincia de Soria. (RODRÍGUEZ PÉREZ, Nerea. 2004)

\subsection{4. ¿Cantores?}

Resulta realmente aventurado afirmar con contundencia que las escenas musicales sin instrumentos puedan representar a cantores. Hemos tomado como referencia para los cantores la posición de los labios o si van acompañados por instrumentistas, pero es imposible ser concluyente en estos puntos. Encontramos cuatro posibles cantores en tres escenas diferentes. 


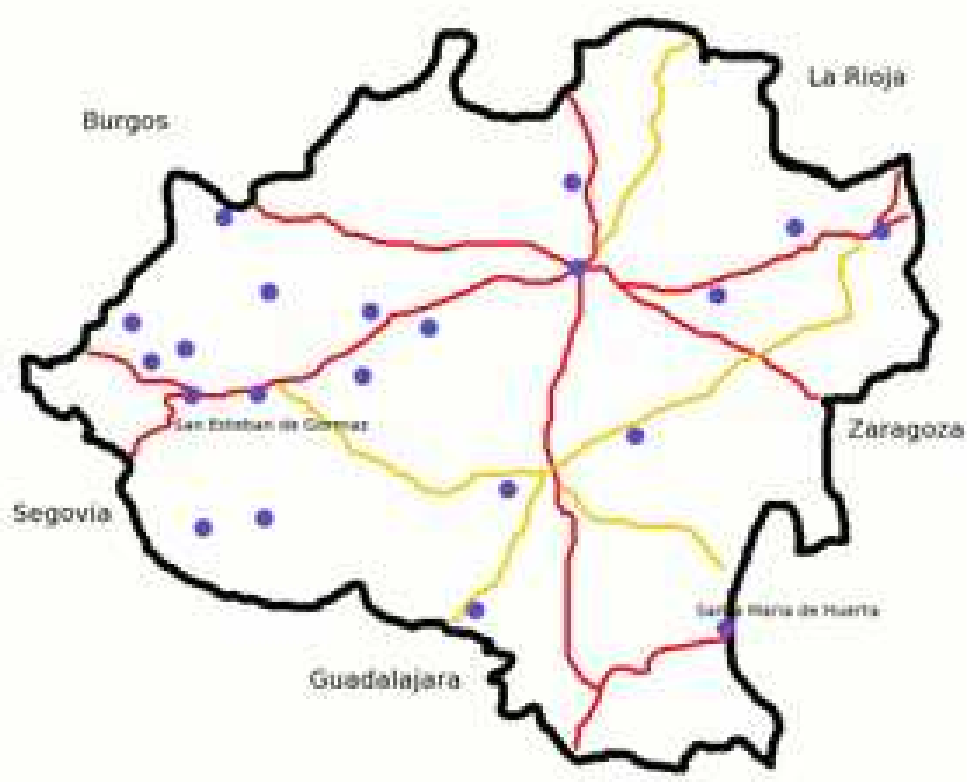

Fig. 26: Mapa de todas las localidades sorianas con imágenes de ¿cantores? en su románico. (RODRÍGUEZ PÉREZ, Nerea. 2013)

La primera de ellas en el Monasterio de Santa María de Huerta corresponde a dos monjes cantando o recitando según los libros de portan. La posición de los labios es en forma de "o", por lo que, tal y como ocurre en el resto de imágenes de este apartado, puede inducir a pensar que son cantores. Las otras dos escenas van acompañadas de tañedores de viola con arco, $\mathrm{y}$, aunque no pertenecen a la misma iglesia, son prácticamente idénticas.
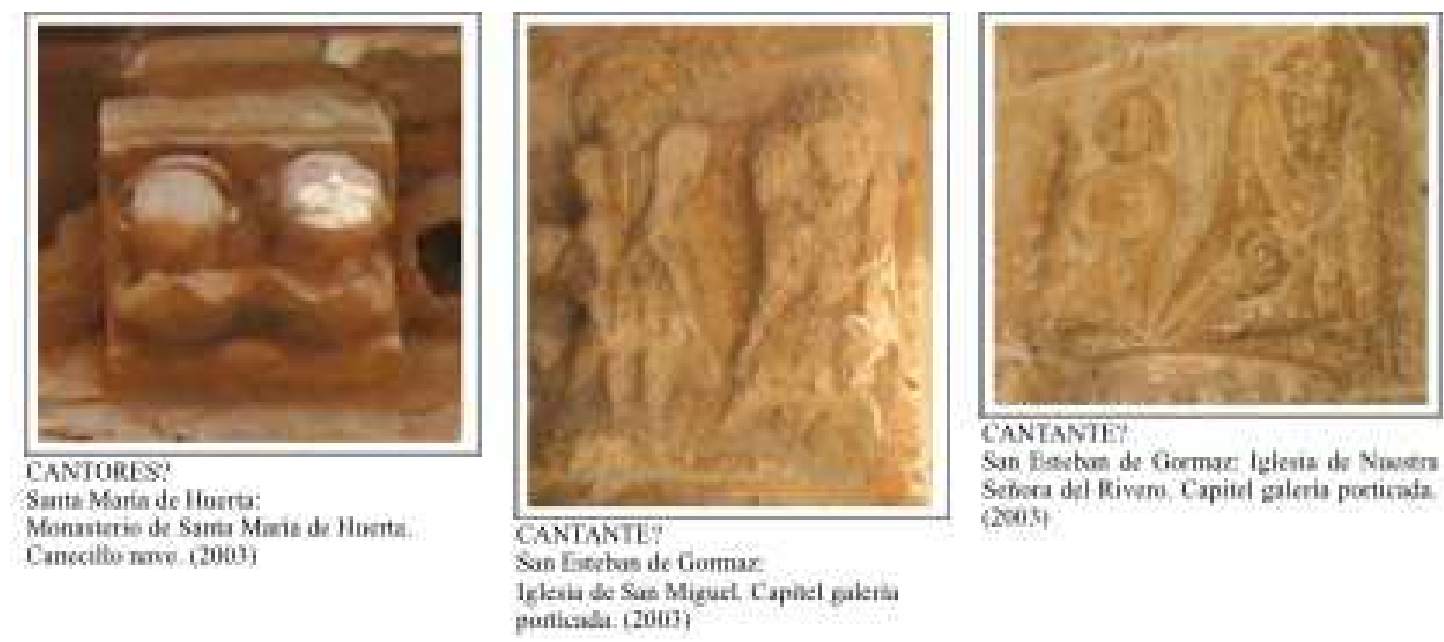

CANTANTE

Sun Beschon de Gormae legesia de Navern Setora del Riven, Capitel galeris portirata. (2005)

Conasiario de Sams Na

Fig. 27: ¿Cantores? Iglesias románicas de la provincia de Soria.

(RODRÍGUEZ PÉREZ, Nerea. 2003)

\section{Conclusiones}

La tipología de los instrumentos o escenas musicales localizadas no es demasiado abundante. Son un total de 59 instrumentos musicales distribuidos de la siguiente manera: 
25 Violas con arco.

2 Violas.

1 Viola en forma de ocho.

2 Tipo laúd.

2 Arpas.

2 Salterios.

3 Rotas.

1 Organistrum.

3 Flautas dulces.

3 Aerófonos de tubo recto.

9 Trompas.

1 Gaita.

1 Tambor.

4 Cantantes.

Centrándonos en los resultados, sin contar Santo Domingo de Soria, podemos observar también que la elaboración de las tallas en un alto porcentaje es muy rudimentaria. Esto, unido al gran deterioro que sufre la mayoría, ha hecho complicada la labor de descripción y de análisis.

Salvo la Catedral de El Burgo de Osma, el claustro de San Pedro (Concatedral de Soria), la iglesia de Nuestra Señora del Rivero de San Esteban de Gormaz y, por supuesto, la ya citada iglesia de Santo Domingo de Soria, las iglesias o ermitas con representaciones musicales son de carácter rural y en ellas se advierten las características del románico rural de la provincia.

Esto hace que casi todo el románico analizado sea muy uniforme y puede que por ello no se haya puesto de manifiesto la variada tipología musical de la época. Lo que destaca, en su lugar, es el uso repetido de modelos estándar con pocas excepciones.

En las grandes edificaciones antes citadas, la talla es mucho más laboriosa y experta, pero sin llegar a ser representaciones especialmente detallistas. Entre todas estas brillan por su belleza y conservación las imágenes de Santo Domingo de Soria.

En cuanto a la localización de las representaciones en los edificios, los lugares más habituales son sin duda los canecillos, unas veces en el ábside de la iglesia, otras en el muro de la nave y otras en las galerías porticadas. En las arquivoltas de las portadas también se localizan canecillos con representaciones musicales, aunque en menor número; también se encuentra algún ejemplo en los capiteles de las galerías porticadas.

La vía de influencia a nivel escultórico es a nuestro juicio silense, ya que se observa con bastante claridad el uso común de modelos musicales, al menos en la iglesia de Santo Domingo de Soria, y las escenas burgalesas de los Veinticuatro Ancianos del Apocalipsis. Otras posibles vías de influencia según las fuentes ya citadas pueden ser el románico francés, el camino de Santiago, el arte mozárabe, los miniaturistas ingleses y los maestros canteros aragoneses.

Se trata solo de un breve resumen del trabajo realizado, pero creemos que es suficiente para hacer ver al lector que el románico rural tiene mucho que ofrecer, que aún esconde muchos secretos de la Edad Media y que desgraciadamente se trata de un patrimonio con grave peligro de desaparecer, tal y como hemos comprobado recorriendo muchos de estos edificios en ruina parcial o total.

La despoblación del mundo rural no favorece la necesaria misión de proteger nuestro patrimonio cultural, pero se deben poner en marcha mecanismos de defensa para que perdure. 
Nerea RODRÍGUEZ PÉREZ, Iconografía musical en el románico de la provincia de Soria

$$
* * * * *
$$

\section{Bibliografía}

Álvarez MARTínEZ, Rosario, 1993, "La iconografía medieval de los Beatos de los siglos X y XI y su procedencia”, Madrid, Anuario del Departamento de Historia y Teoría del Arte, Univ. Autónoma de Madrid, p. 201-218.

Álvarez MARTíneZ, Rosario, 1982, Los instrumentos medievales en la plástica española durante la Edad Media, Madrid, Tesis doctoral, Univ. Complutense de Madrid.

Álvarez MARTínez, Rosario, 1987, "Los instrumentos musicales en los códices alfonsinos: su tipología, su uso y su origen. Algunos problemas iconográficos", Revista de Musicología, x, 1, p. 67-104.

ANGLÉS, Higinio, 1970, Historia de la música medieval en Navarra, Pamplona, Diputación Floral de Navarra, Institución "Príncipe de Viana".

ARtigas y Corominas, Pelayo, 1986, "El monasterio de Santa Clara de Soria", Celtiberia, $\mathrm{n}^{\circ} 71$, Soria.

BALLESTER, Jordi, 1988, Els instruments musical en els retaules marians tardomedievals a la Corona Catalano-Aragonesa, Barcelona, Tesis de licenciatura, Univ. Autónoma de Barcelona.

Beato de Liébana, facsímil 1992, Apocalipsis de San Juan Apóstol, Valencia, Ed. Vicent García Editores, S.A.

Bordas, Cristina; ReY, José; De VICENTE, Antonio, 1994, "Bibliografía sobre iconografía musical española", AEDOM Boletín de la Asociación Española de Documentación Musical, Año 1, n ${ }^{\circ}$, Enero-Junio, p. 13-57, Addenda I en idem, II, 1, 1995, p. 81-88, Addenda II en idem, V, 2, 1998, p. 85-92.

BORDAS IBÁNEZ, Cristina, 2001, "Música y artes plásticas. Una presentación y otra mirada más al Pórtico de la Gloria." Campos Interdisciplinares de la Musicología. Volumen II, Madrid, Actas del V Congreso de la Sociedad Española de Musicología (Barcelona, 25-28 de octubre de 2000), p. 1227-1242.

Casa Martínez, Carlos de la, 1986, "Datos para la historia del monasterio de Santa Clara de Soria. Catálogo sifilográfico de su archivo" Celtiberia, $\mathrm{n}^{\circ} 7$, Soria, Centro de estudios sorianos, p. 58-68.

Castilla y León. Soria plano-guía, 2002, Ed. Junta de Castilla y León.

COBRERos, Jaime, 1989, Itinerarios románicos por el Alto Aragón. El símbolo como expresión de lo sagrado, Madrid, Ed. Encuentro.

DAVY, Marie Madelaire, 1996, Iniciación a la simbología románica: el siglo XII, Torrejón de Ardoz, Ed. Akal.

Diago Hernando, Máximo, 1990, "Seminario Alfonso VIII y su época", II Curso de Cultura Medieval, Aguilar del Campoo 1-6 Octubre, ed. Centro de estudios del Románico.

Diago Hernando, Máximo, (1991-1992), "Repoblación de integración política en el reino de Castilla del ámbito de la tierra de Soria", RICUS (Geografía e historia) XI ,3 , Soria, Ed. Colegio Universitario de Soria, p. 37-58.

Diago Hernando, Máximo, 1993, Estructuras de poder en Soria a fines de la Edad Media. ed. Consejería de Cultura y Turismo. Junta de Castilla y León, p. 17-23, 367, 368.

FOCILLON, Henry, 1986, La escultura románica. Investigaciones sobre la historia de las formas, Madrid, Ed. Akal. Arte y Estética.

FRÍAS BALSA, José Vicente, 1978, "Los obispos de Osma y el Dogma de la Inmaculada" Revista de Soria, $\mathrm{n}^{\circ} 36$, Soria. 
FrONTÓN SIMÓN, Isabel, 1996, "El pórtico de la iglesia románica del monasterio de Silos. Datos para la reconstrucción iconográfica de su portada exterior" Boletín del Museo e Instituto Camón Aznar $\mathrm{n}^{\circ}$ LXIV.

García i ACón, F., Nin i Catalá, J., 2000, Soria. Plano de ciudad. Mapa de provincia. Rutas turísticas. Índices toponímicos, Barcelona, ed. Distrimapas telstar.

GaYA NuÑo, Juan Antonio, 1946, El románico en la provincia de Soria, Madrid, ed. Biblioteca de Historia del Arte del consejo superior de investigaciones científicas, centro de estudios sorianos, (edición facsímil de 2003).

GAYA NuÑo, Juan Antonio, 1963, "Poitiers y Soria, hermanas románicas". Diario de Barcelona. (14-XII-1963).

GAYA NuÑo, Juan Antonio, 1976, “Artistas y Artesanos del Románico Español” Goya 130, p. 214-219.

GÓMEZ BARRERA, Juan Antonio, 2000, “Aproximación al estudio iconográfico de la primera arquivolta del Pórtico de Santo Tomé (Soria)". Butlletí de la Reial Académia Catalana de Belles Arts de Sant Jordi, XIV.

GONZÁLEZ HERRANZ, Raimundo, 1998, "Representaciones musicales en la iconografía medieval". Anales de Historia del Arte, no 8, p. 67-96.

GonZÁleZ, Julio, 1960, El reino de Castilla en la época de Alfonso VIII, Madrid, ed. CSIC.

Herbosa, Vicente, 1999, El Románico en la Provincia de Soria, León, ed. Lancia.

IZQUIERDO BERTIZ, José María, 1985, "El arte Románico en Soria". Historia de Soria, Soria, ed. Centro de estudios Sorianos, p. 265-296.

JimÉnEZ GonZALO, Carmelo, 1985, Santo Domingo. Iglesia y Monasterio, Soria, Ed. El autor.

JUAN I NEBOT, M. Antònia, 1998, "Versión castellana de la clasificación de instrumentos musicales según Erich von Hornbostel y Curtt Sachs (Galpin Society Journal XIV, 1961)", Nasarre, XIV, 1, Zaragoza, pp. 365-387.

KARGE, Henrik, 1995, La catedral de Burgos y la arquitectura del siglo XIII en Francia y España, Valladolid, Ed. Consejería de Cultura y Turismo.

KING, Georgiana Goddard, 1926, "The problem of the Duero" Art Studies, 3, p. 3-11.

La catedral de Burgo de Osma. Guía turística, Soria, edita el Cabildo de la S. I. Catedral, 1975, p. 25-30.

LAFORA, Carlos, 1988, Por los caminos del Románico Porticado. Una fórmula arquitectónica para albergar el derecho a la libertad, Madrid, Ed. Encuentro. Colección La noche de los tiempos.

LOPERraez Corvalan, Juan, 1788, Descripción histórica del Obispado de Osma, Madrid, 3 volúmenes, ed. Turner.

LóPez-CALO, José, 1982, La música Medieval en Galicia, La Coruña, ed. Fundación Pedro Barrié de la Maza.

LóPeZ-CAlo, José (coordinador), 1993, Los instrumentos del Pórtico de la Gloria. Su reconstrucción y la música de su tiempo, Vol. 1 y 2, La Coruña, ed. Fundación Pedro Barrié de la Maza Conde de Fenosa.

Mapa Provincial Soria, Madrid, ed. Ministerio de Fomento Instituto geográfico Nacional, 1999.

Marichalar, Amalio de (Conde de Ripalda), 1972, "Iglesia Románica de Santo Domingo (antigua parroquia de Santo Tomé)", Arte e historia, Soria.

Moreno Ayola, Eugenio y TARACENA AguirRe, Blas, 1983, Inventario de los Archivos Históricos Municipales y Especiales de la Provincia de Soria, Soria, p. 97, 98, 104.

NúÑEZ MARQues, Vicente. , 1949, Guia de la Iglesia Catedral del Burgo de Osma y Breve Historia del Obispado de Osma, Burgo de Osma. 
OCÓN AlONSO, David, 1992, "Alfonso VIII, la llegada de las corrientes artísticas de la corte inglesa y el bizantinismo de la escultura hispana a finales del siglo XII" II Curso de Cultura Medieval: Alfonso VIII y su época, Madrid, Aguilar del Campoo, 1-16 de octubre de 1990, p.313.

PALACIOS MADRID, Francisco, 1977, "Los señores de Soria y su castillo en el siglo XII", Celtiberia, $\mathrm{n}^{\circ} 53$, Soria, ed. Centro de Estudios Sorianos.

PALOMERO ARAGÓN, Félix, 1987, "Aproximación a la escultura monumental Románica de la Ermita de Santa María de Tiermes." Celtiberia n ${ }^{\circ} 73$, Soria, ed. Centro de Estudios Sorianos, p. 127-154.

PERALES DE LA CAL, Ramón, 1984, Iconografía musical arqueológica de Soria” Actas del primer Symposium de Arqueología Soriana, Soria, p. 541-555.

PÉreZ-Rioja, José Antonio, 1985, Historia de Soria, Soria, ed. Centro de Estudios Sorianos (CSIC), p. 217-242.

PITA ANDRADE, José Manuel, 1933, Artes y artistas. Escultura románica en Castilla. Los maestros de Oviedo y Ávila, Madrid, Ed. Instituto Diego Velázquez del CSIC.

RAulT, Christian, 2001, www. Christianrault.com/sp/publicaciones " La gigue: 1'autre vièle médiévale?", París.

REGUERAS, Fernando, 1990, La arquitectura mozárabe en León y Castilla, ed. por Junta de Castilla y León.

ReY, Juan José y NAVARro, Antonio, 1993, Los instrumentos de púa en España. Bandurria, cítola y "laudes españoles", Madrid, ed. Alianza.

RIDRUEJO GIL, María Antonia y María del Pilar, 1945, "Cuatro frontales románicos de Soria" Archivo Español de Arte, p. 3-12.

Ríos Álvaro, Koldo, 1999, Lista de Instrumentos de Música Occidentales. Anotada desde un punto de vista iconográfico Terence Ford, Traducida y Adaptada al español por Koldo Ríos Álvaro. Colección Cuadernos de Documentación Musical $\mathrm{n}^{\circ} 2$. Asociación Española de Documentación Musical.

ROMERO DE LECEA, Carlos, 1977, Trompetas y cítaras en los códices de Beato de Liébana, Madrid, RABASF.

RuIZ EZQuerdo, Juan José, 1985, “Los tímpanos románicos sorianos” Celtiberia XXXV, Soria, ed. Centro de Estudios Sorianos, p.35-62.

Ruiz MonTEJo, Inés, 1989, "Concepto y método del románico rural” Anales de Historia del Arte 1, p.21-37.

SAINZ, Elena: "Estudio Iconográfico y simbólico de la fachada de Santo Domingo", Celtiberia $\mathrm{n}^{\mathrm{o}}$ 66, Soria, ed. Centro de Estudios Sorianos, p. 363-372.

VAL VALDIVIESO, M $^{\circ}$ Isabel del, 1985, "Introducción al estudio del obispado de Osma en la Baja Edad Media", Celtiberia n ${ }^{\circ}$ 70, Soria, ed. Centro de Estudios Sorianos, p. 211252.

Villanueva Abelairas, Carlos, 1988, El pórtico de la Gloria. Música, arte y pensamiento, A Coruña, ed. Xunta de Galicia.

VV.AA., 1983, Ciclo de conferencias sobre el Románico y el Camino de Santiago, Palencia , Organizado por el Departamento de Cultura de la Excma. Diputación Provincial de Palencia.

VV.AA., 1986, VII Centenario de las Clarisas en Soria, Soria, Ed. Centro de Estudios Sorianos. Consejo Superior de Investigaciones Científicas, p. 202-207.

VV.AA., 1994, Santo Domingo de Soria la presencia del color. ed. Biop, S.L.

VV.AA., 2001, Soria Románica. El arte Románico en la Diócesis de Osma-Soria, Aguilar de Campoo (Palencia), Por la Fundación de Santa María La Real.

VV.AA., 2002 Enciclopedia del Románico en Castilla y León. Burgos, Aguilar del Campoo (Palencia), Ed. Fundación de Santa María La Real, Centro de Estudios del Románico, Dirección: M.A. García Guinea y J.M. Pérez González, Vol. 1, 2, 3 y 4. 
Nerea RODRÍGUEZ PÉREZ, Iconografía musical en el románico de la provincia de Soria

VV.AA., 2002, Enciclopedia del Románico en Castilla y León. Soria, Aguilar del Campoo (Palencia), Ed. Fundación de Santa María La Real, Centro de Estudios del Románico, Dirección: M.A. García Guinea y J.M. Pérez González, Vol. 1, 2, 3.

VV.AA., 1973, Enciclopedia Universal Ilustrada Europeo Americana, Ed. Espasa-Calpe S.A. Tomo 54 "Santiago", p. 249, 252, 264-266.

VV.AA., 1992, Las Catedrales de Castilla y León, dir. Vicente Pastor, Ed. Edilesa Junta de Castilla y León, p.101.

VV.AA., 2012, "IMAGENesMUSICA", Madrid, Proyecto Iconografía Musical UCM, edita AEDOM.

www.soriaymás.es : "Influencias francesas en el Románico Soriano", "Hermetismo y alquimia en Santo Tomé de Soria".

Zamora LuCAS, F., 1973, "La dehesa de San Andrés en la historia" Celtiberia, nº45, Soria, ed. Centro de Estudios Sorianos, p. 25-35. 